\title{
Towards defining muscular regions of interest from axial magnetic resonance imaging with anatomical cross-reference: A scoping review of lateral hip musculature
}

\author{
Zuzana Perraton \\ La Trobe University \\ Peter Lawrenson \\ La Trobe University \\ Andrea B. Mosler \\ La Trobe University \\ James M. Elliott \\ University of Sydney \\ Kenneth A. Weber II \\ Stanford University \\ Natasha N. Flack \\ The University of Otago \\ Jon Cornwall \\ University of Otago, Otago Medical School \\ Rebecca J. Crawford \\ Body Urbanist and Consultant \\ Christopher Stewart \\ La Trobe University \\ Adam I. Semciw ( $\square$ a.semciw@latrobe.edu.au ) \\ La Trobe University
}

\section{Research Article}

Keywords: Hip muscles, Magnetic resonance imaging, muscle morphology, muscle fat infiltration, manual segmentation

Posted Date: February 21st, 2022

DOI: https://doi.org/10.21203/rs.3.rs-1320324/v1

License: @ (i) This work is licensed under a Creative Commons Attribution 4.0 International License. Read Full License 


\section{Abstract \\ Background}

Measures of hip muscle morphology and composition (e.g., muscle size and fatty infiltration) are possible with magnetic resonance imaging (MRI). Standardised protocols or guidelines do not exist for evaluation of hip muscle characteristics, hindering reliable and valid inter-study analysis. This scoping review aimed to collate and synthesise MRI methods for measuring lateral hip muscle size and fatty infiltration to inform the future development of standardised protocols.

\section{Methods}

Five electronic databases (Medline, CINAHL, Embase, SportsDISCUS and AMED) were searched. Healthy or musculoskeletal pain populations that used MRI to assess lateral hip muscle size and fatty infiltration were included. Lateral hip muscles of interest included tensor fascia late (TFL), gluteus maximus, gluteus medius, and gluteus minimus. Data on MRI parameters, axial slice location, muscle size and fatty infiltrate measures were collected and analysed. Cross referencing for anatomical locations were made between MRI axial slice and $\mathrm{E}-12$ anatomical plastinate sections.

\section{Results}

From 2692 identified publications, 79 studies contributed data on volume $(n=31)$, cross sectional area (CSA) $(n=24)$, and fatty infiltration $(n=40)$. Heterogeneity was observed for MRI parameters and anatomical boundaries scrutinizing hip muscle size and fatty infiltration. Seven single level axial slices were identified that provided consistent CSA measurement, including three for both gluteus maximus and TFL, and four for both gluteus medius and minimus. For assessment of fatty infiltration, six axial slice locations were identified including two for TFL, and four for each of the gluteal muscles.

\section{Conclusions}

Several consistent anatomical levels were identified for single axial MR slice to facilitate muscle size and fatty infiltration muscle measures at the hip, providing the basis for reliable and accurate data synthesis and improvements in the validity of future between studies analyses. This work establishes the platform for standardised methods for the MRI assessment of lateral hip musculature and will aid in the examination of musculoskeletal conditions around the hip joint. Further studies into whole muscle measures are required to further optimise methodological parameters for hip muscle assessment.

\section{Background}

Magnetic resonance imaging (MRI) has been used to assess skeletal muscle morphology and composition for over four decades (1-3). Assessment of skeletal muscle with MRI can contribute to improved understanding of normal responses to physical activity and changes associated with healthy ageing, muscle injury, and pathology $(1,4)$. Advancing MRI technologies, including a range of faster, higher resolution techniques continue to emerge with the aim of improving visualisation and quantification of muscle characteristics (5-7).

The use of MRI to evaluate hip muscle morphology and composition in healthy and musculoskeletal pain populations is becoming more common. Interest in hip muscle size and quality is driven by the knowledge that the muscles spanning the hip joint contribute to hip joint forces (8-10). The capacity of a muscle to generate force has been linked to its size, including cross sectional area (CSA) and volume $(11,12)$. Hip joint forces have, in turn, been associated with joint health, pain and/or other symptoms $(13,14)$. How the size and quality of muscles spanning the hip joint contribute to hip joint forces is an area of particular interest (8-10).

The lateral hip muscles including the gluteus maximus, gluteus medius, gluteus minimus and the tensor fascia latae (TFL) generate forces around the hip joint for both movement and stability, particularly in single leg stance and during gait (15-18). In people with musculoskeletal hip pain, several studies have demonstrated muscle atrophy and increased fatty infiltration of the lateral hip muscles when compared to age-matched controls and asymptomatic contralateral limb (19-25). As such, muscle size and fatty infiltration present as possible targets for interventions. Preliminary evidence indicates that these muscles can respond to exercises targeting the 
hip and other regions (26-28). Further work assessing size and adiposity of these muscles will help to establish the most responsive type and dose of exercise to use, as well as the relationship to symptom recovery.

Recent systematic reviews have highlighted heterogeneity and inconsistencies in published MRI methods designed to assess muscle size and composition of the lateral hip muscles $(7,17,29)$. Common to all studies remains the challenges of accurately differentiating and consistently measuring the borders of individual muscles on conventional MRI which may lead to difficulties in comparing results. For the lateral hip muscles, the individual gluteal muscle borders are difficult to identify at the region between the upper border of the acetabulum and the superior tip of the greater trochanter $(26,30)$. The use of high-resolution E-12 anatomical plastinates alongside MRI, may improve the ability to visualise anatomical regions by comparing and identifying key features at specific locations (5, 31, 32). Currently, there is an urgent need for robust and reproducible MRI methods for identifying, measuring, and interpreting hip muscle images, particularly to enable comparison of results across studies and data pooling.

The primary aim of this review was to define standardised MRI methods for assessing lateral hip muscle size and fatty infiltration. A secondary aim was to provide illustrative comparisons between MRI and high-resolution E-12 anatomical plastinates using standardised locations as determined from the literature to improve visibility of muscle borders.

\section{Method}

This review followed the PRISMA guideline extension for scoping reviews $(33,34)$ and was prospectively registered on the open science framework platform (https://osf.io/5nyuq/).

\section{Search strategy}

Five electronic databases (Medline, CINAHL, Embase, SportDISCUS and AMED) were searched from inception up to Nov 1st 2021. No language limits were placed. Search terms were mapped to three main concepts; (i) Magnetic resonance imaging, (ii) lateral hip muscles (i.e., TFL, gluteus maximus, gluteus medius and gluteus minimus) and, (iii) muscle morphology and composition (i.e. muscle size and fatty infiltration). Synonyms within each concept were mapped to subject headings, where possible, or searched under title, abstract and/or keywords. Results within each concept were combined with 'OR' and between concepts combined with "AND" (Additional file 1).

The search strategy was modified according to the specifications of each database. Manual citation tracking and reference checking of included articles was performed. Ahead of print lists of journals included in the study were screened for additional studies. Grey literature, such as internal reports and conference proceedings, were searched for further eligible studies.

Titles and abstracts of studies retrieved from the databases, as well as those identified from reference-checking and citation-tracking, were screened for eligibility by two reviewers (ZP and CS). Any disagreements in the eligibility of a study were discussed and a consensus reached with the aid of a third reviewer (AS). The final yield was exported into Covidence online software (www.covidence.org) for eligibility screening against inclusion and exclusion criteria.

\section{Inclusion/exclusion criteria}

Studies with participants of any age and either healthy or musculoskeletal pain populations were included. All MRI investigations which assessed lateral hip muscle size and/or fatty infiltrate were included. Cadaveric studies were excluded. Studies were excluded if muscles were assessed as a group rather than reported individually (e.g., gluteals) and if using other imaging modalities (e.g., ultrasound) without comparison to MRI. In line with previous publications establishing regions of interest in axial images (5, 31, 35), studies using axial MRI slices for size and fatty infiltration measures were included. All published peer-reviewed studies were included; opinion pieces/editorials, systematic reviews, narrative reviews, conference abstracts and single case studies were excluded.

For our secondary aim, axial MRI images were compared to E12 anatomical plastinate sections at corresponding anatomical levels to illustrate differences, and thus identify regional morphology. The E12 anatomical plastinate sections are part of the anatomy collection, in the WD Trotter Anatomy Museum at the University of Otago. Approval to use images of the E12 plastinate sections was granted by the Department of Anatomy, University of Otago.

\section{Risk of bias (quality) assessment}


The primary aim of this review was to report MRI methods rather than individual study results. As such, and in line with the PRISMA extension for scoping reviews (PRISMA-ScR) checklist $(34,36)$, a risk of bias assessment was not conducted.

\section{Data extraction}

A standardised data extraction form was used to extract data relating to the individual study characteristics (study purpose, design (37), population, sample size). Details on MRI parameters (e.g. scanner field strength, manufacturer, MRI sequence, slice selection \& thickness), specific lateral hip muscles assessed, and details of size (volume and CSA) and fatty infiltration outcomes were collected by two authors (ZP and NF). Any discrepancies were discussed between authors and conflicts resolved by a third author (AS) if required.

Reliability data were collected to assess consistency of the MRI methodology between included studies. Intraclass correlation coefficient (ICC) and the kappa coefficient ( $k$ ) statistic are frequently used as a measure of intra- and inter-rater reliability $(38,39)$. ICC values were interpreted as values less than 0.5 as poor reliability, $0.5-0.75$ as moderate reliability, $0.75-0.9$ as good reliability, and values greater than 0.90 as excellent reliability (38). Kappa coefficient were interpreted as values $\leq 0.20$ as none to slight, $0.21-0.40$ as fair, $0.41-0.60$ as moderate, $0.61-0.80$ as substantial, and $0.81-1.00$ as almost perfect agreement (40).

\section{Analysis/ Synthesis}

Descriptive statistics were used to summarize findings across studies for MRI parameter and anatomical locations for regions of interests. Data for muscle size were grouped into volume and CSA. Fatty infiltration measures were grouped into qualitative and quantitative methods. Qualitative measures could include the Goutallier classification system (41), which grades muscle according to the relative amount of fatty tissue that is present, progressing from 0 (regular muscular tissue, no intramuscular fat) to 4 (more fat than muscle), and the Quartile classification (42) which also adopts a 5-step grading system ( $0 \%, 25 \%, 50 \%, 75 \%$ or $100 \%)$ to define the percentage of fatty tissue that is present. Quantitative measures could include various calculations incorporating fat-value pixels.

Anatomical levels for measuring CSA and fatty infiltration were collected. When a single anatomical level contained multiple anatomical features, the most easily identifiable and distinguishable anatomical feature on axial MRI slice was extracted. Axial MRI DIXON sequence images and E12 anatomical plastinate sections were cross referenced. Anatomical levels were compared on a 3D MRI image.

\section{Results}

The initial search identified 2,692 studies, from which 1,614 duplicates were removed with a further 813 removed after title and abstract screening. An additional 176 were removed following full text screening, which resulted in 78 studies from 81 publications that met the inclusion criteria (Additional file 2 and 3).

Trends in publication of MRI studies: 1992 to 2020

Frequency of publication of MRI studies has increased steadily since 1992, growing from one study (43) to 12 in 2020 (44-55) (Figure 1A). Across the included studies, 17 countries were represented: Australia $(n=16)$, Japan $(n=11)$, Germany $(n=10)$, USA ( $n=10)$, United Kingdom $(n=7)$, Switzerland (5), Finland $(n=4)$, France $(n=3)$, Netherlands $(n=3)$, Spain $(n=3)$, China $(n=2)$, Turkey $(n=2)$, Canada $(n=1)$, New Zealand $(n=1)$, Norway $(n=1)$, Poland $(n=1)$. A range of study designs were used including nine randomised controlled trials, 33 prospective cohort, 10 retrospective cohort, 15 case-control and 10 case series study designs (Figure 1B).

\section{Patient and non-patient populations}

Twenty-three studies across 25 publications investigated hip related musculoskeletal pain (e.g., hip osteoarthritis, lateral hip pain and intra-articular hip joint pathologies) (Figure 1C). Three studies examined non-hip related musculoskeletal pain which included low back pain $(56,57)$ and patellofemoral joint osteoarthritis $(58)$. Twenty-nine studies, across 33 publications, used healthy comparison groups and 26 studies explored one of three surgical presentations (i.e., total hip arthroplasty, hip arthroscopy and surgical correction for hip dysplasia) (Figure 1C). Gluteus medius was the most frequently assessed lateral hip muscle (Figure 1D). Fifty-four studies measured muscle size and 40 studies investigated fatty infiltration (Table 1).

\section{Measurement of muscle size and quality}


Thirty-six studies reported the profession of the individual(s) interpreting MRIs and calculating size and fatty infiltration measures. The most frequently cited professionals were radiologists (31 studies) with 15 studies reporting radiologists with further training in

musculoskeletal presentations. Other health professionals included orthopaedic surgeons and physiotherapists. Ten studies (44, 57, 5966) reported years of experience for those who interpreted the MRIs, which ranged from 1 year to 28 years.

For volume measures, ICC scores reflected good to excellent reliability, with data ranging from 0.87 to 0.99 for intra-reliability and 0.80 to 0.99 for inter-reliability. For CSA, reliability was moderate to excellent with scores ranging from 0.70 to 1.00 for intra-rater reliability and 0.70 to 0.99 for inter-rater reliability. Fatty infiltration ICC values also indicated moderate to excellent reliability with scores ranging from 0.70 to 0.99 for intra-rater reliability and 0.70 to 0.98 for inter-rater reliability. The kappa coefficient scores indicated fair to almost perfect agreement between and among studies (intra-rater reliability $k$ range 0.463 - 0.93; inter-rater reliability $k$ range, 0.51- 0.91) (Table 1). No study reported scan to rescan reliability.

\section{MRI parameters}

The MRI parameters of all studies are summarised in Table 1. Two MRI field strengths were reported, 1.5 Tesla and 3 Tesla. A wide range of MRI sequences were used across the studies, with many incorporating several sequence types, both T1-and T2-weighted, with and without fat suppression. Slice thickness ranged from $0.5 \mathrm{~mm}$ to $15 \mathrm{~mm}$, with 16 studies $(20.3 \%)$ not reporting slice thickness. Acquisition time ranged from $2 \mathrm{hrs} 32 \mathrm{mins}(67)$ to $1 \mathrm{~min} 29 \mathrm{~s}(68)$.

All studies that reported patient positioning specified a supine position with legs extended and hips in neutral, except three studies (45, $69,70)$ that used pillows under the knees for comfort, and two studies $(44,46)$ placing the hips into internal rotation.

Table 1 MRI parameters for individual studies

\section{Muscle size measures}

Lateral hip muscle volume was measured in 31 studies and CSA was measured in 24 studies, (Table 2 and 3 ). For volume measures, manual segmentation techniques were most frequently used (77.4\%) compared to automated. For CSA, all studies used manual segmenting techniques.

\section{Volume measurement outcomes}

Whole muscle volume was calculated for 28 studies $(90.3 \%)$, while two $(26,52)$ measured partial muscle volume. To calculate volume, all studies incorporated sums of CSA estimates. Seventeen (54.8\%) studies also incorporated slice thickness and five (16.1\%) normalised calculations to either individual height or mass (Table 2).

Table 2 Volume measurement outcomes for individual studies

\section{Cross-sectional area measurement outcomes and axial anatomical slice location}

Five studies calculated CSA from multiple slices either by using the mean derived from several consecutive slices or assessing CSA at two predetermined locations (Table 3). Single axial slices were chosen at a pre-determined anatomical locations for all other studies except for two studies $(71,72)$, which measured at the single slice with the greatest CSA for the individual muscle.

Table 3 Cross sectional area measurement outcomes for individual studies

Seven anatomical levels were identified as locations where CSA can be measured for the lateral hip muscles (Figures $2,3 \& 4)$ ). These include i) anterior superior iliac spine (ASIS) (73-75) ii) half way between the iliac crest and the superior tip of the greater trochanter (59) iii) anterior inferior iliac spine (AIIS) (73) iv) upper border of the acetabulum $(46,76,77)$ v) superior tip of the greater trochanter $(45,62,69,78-81)$ vi) lower border of the acetabulum $(25,76,77)$ and vii) lesser trochanter $(57)(75)$.

Fig. 2 3-D representation of anatomical levels for each lateral hip muscle

When comparing MRI images to E-12 anatomical plastinates (Fig. 3 \& 4), the E-12 anatomical plastinates provide better visualisation of muscle borders. At levels AllS and the upper border of the acetabulum, the muscle borders between gluteus medius and piriformis are better visualised on the E-12 anatomical plastinates with detail of individual muscle fibre directions demarcating the individual muscles 
(Fig. 5). For levels at superior tip of greater trochanter and below, the TFL border is better visualised on the E-12 anatomical plastinates against neighbouring muscle borders including the gluteus medius and rectus femoris.

Fig. 3 Axial DIXON sequence MRI and E-12 anatomical plastinate comparison at anatomical levels for cross sectional area measurement above the hip joint. A At the level of anterior superior iliac spine B Halfway between the iliac crest and the superior tip of the greater trochanter $\mathbf{C}$ Anterior inferior iliac spine; square dotted box surrounds enlarged morphological region of interest (fig. 4); 1gluteus minimus; 2- gluteus medius; 3- gluteus maximus; 4- TFL; 5- ilium; 6- iliacus; 7- psoas major; 8- rectus abdominis

Fig. 4 Axial DIXON sequence MRI and E-12 anatomical plastinate comparison at anatomical levels for cross sectional area measurement at and below hip joint. A upper border of the acetabulum $\mathbf{B}$ superior tip of the greater trochanter $\mathbf{C}$ lower border of the acetabulum D lesser trochanter; 1- gluteus minimus; 2- gluteus medius; 3- gluteus maximus; 4- TFL; 5- acetabulum; 6- Iliacus; 9Acetabulum; 10- Piriformis; 11- Iliopsoas; 12- Sartorius; 13-Rectus femoris; 14- Femoral head; 15- Greater trochanter; 16- lesser trochanter; 17-Vastus lateralis; 18- Pectineus; 19: Adductor brevis; 20- Adductor magnus; 21-Quadratus femoris

Fig. 5 Enlarged region of interest at the level of anterior inferior iliac spine. A Axial DIXON sequence MRI B E-12 anatomical plastinate C Schematic illustration; round circle indicates feature of interest; Red line- gluteus minimus; Green line- gluteus medius; Dashed red linepartition between gluteus medius and piriformis; Dashed grey line- partition between gluteus maximus with both gluteus medius and piriformis; Red circle- highlights angles between partitions to help identify separation between piriformis and gluteus medius

Some same slice locations were described in multiple ways as these levels contained multiple identifying features. For example the slice location at the level of the tip of the greater trochanter (level vi) is consistent with the level described as the centre of the femoral head $(62,79,80)$, and the level where the femoral head has the greatest CSA (45), depending on slice thickness. Other slice locations were at a pre-set distance from an anatomical feature including $20 \mathrm{~mm}$ distal to the proximal aspect of the femoral head (82) for gluteus maximus and $15 \mathrm{~mm}$ from the superior margin of the acetabulum (67) for gluteus medius and minimus.

\section{Intramuscular fatty infiltration measurement outcomes and axial anatomical slice location}

Forty studies measured intra-muscular fatty infiltration (Table 4). Qualitative measures of fatty infiltrate were used by 30 studies with the Goutellier classification being the most frequently used. Quantification methods, using a ratio of pixel intensity from fat and water images were used by 10 studies. This technique has become more utilised over recent years.

Gluteus medius and/or gluteus minimus were further divided into compartments in 11 studies. Gluteus medius was divided into three equal compartments (anterior, middle and posterior) by nine studies and two equal compartments (anterior, posterior) by one study. Similarly, gluteus minimus was divided into three equal compartments (anterior, middle and posterior) by seven studies and into two equal parts (anterior and posterior) by two studies. The TFL and gluteus maximus were not divided into compartments for intramuscular fatty infiltration measurement.

Table 4 Fatty infiltration measurement outcomes for individual studies

Six anatomical levels were identified as locations for fatty infiltration measurement of the lateral hip muscles (Figure 6). Two levels were identified for TFL, four levels were identified for gluteus maximus, gluteus medius and gluteus minimus muscles. Four studies (53, 83-85) described quantitative measures of fatty infiltration for whole muscle.

\section{Tensor fascia latae}

The two anatomical levels for TFL fatty infiltration assessment included the superior tip of the greater trochanter $(79,81)$ and the lesser trochanter $(67,74,75)$. The level at the greater trochanter was consistent with other anatomical features including the centre of the femoral head $(79)$ and the fovea capitis $(19,21,22)$. The ischial tuberosity was described in one study (86) and can span multiple slices. The greatest axial CSA was described in one study (87).

\section{Gluteus maximus}

The four levels for gluteus maximus fatty infiltration assessment are i) the distance at one third the distance from the iliac crest to the superior tip of the greater trochanter(19) ii) greater sciatic foramen (superior most part) $(19,21,22,42)$ iii) two thirds the distance from the iliac crest to the superior tip of the greater trochanter(19) iv) the superior tip of the greater trochanter $(19,88)$. The level where the 
femoral head has a round configuration(66) and where it has the greatest circumference(19) was deemed similar to the level at the greater trochanter.

\section{Gluteus medius and minimus}

Gluteus medius and gluteus minimus were frequently assessed individually at the same level within a study. The four levels for gluteus medius and gluteus minimus fatty infiltration assessment are i) the distance at one third the distance from the iliac crest to the superior tip of the greater trochanter $(19,59,61,79,87)$ ii) anterior superior iliac spine $(74,75)$ iii) greater sciatic foramen (superior most part) $(19,21,22,42)$ and iv) two thirds the distance from the iliac crest to the superior tip of the greater trochanter $(19,59,61,79,87,89-$ 92).

Other levels described included pre-determined distances from anatomical features and included $15 \mathrm{~mm}$ superior to the upper margin of the acetabulum(67), three and six slices proximal to greater trochanter with slice thickness set at $6 \mathrm{~mm}(93), 30 \mathrm{~mm}$ proximal to greater trochanter (94). Descriptions of levels that could span multiple axial slices included the level of the acetabulum(67, 88) and the ipsilateral sacroiliac joint (95).

Fig. 6 Anatomical levels of interest for fatty infiltration measurement outcomes

\section{Machine learning}

Overall machine learning was incorporated in $16(20.3 \%)$ of the studies. For size measures, eight $(25.8 \%)$ studies reporting volume either used automatic or semi-automatic tracing methods while no study reporting CSA incorporated machine learning. For fatty infiltration, 10 (25.0\%) studies used machine learning to identify and quantify water and fat value pixels within regions of interest.

\section{Discussion}

This scoping review aimed to define standardised MRI methods for assessing lateral hip muscle size and fatty infiltration. Heterogeneity across the reported MRI parameters when measuring size and fatty infiltration was found, highlighting the need for a consistent and worldwide program in future research. We report seven identifiable anatomical locations for measurement of lateral hip muscle CSA and six identifiable anatomical locations for fatty infiltration at single slice measurement. We also identified new and emerging technology in machine learning for automated muscle segmentation techniques for size and fatty infiltration measures.

\section{MRI acquisition parameters and methodology}

MRI parameters determine the quality of images that can influence the results of a study. The use of heterogenous MRI parameters, as found in this review, can complicate comparisons and future pooling of data between studies. Global, multi-centred collaborations aimed to provide MRI protocol consensus have been undertaken for other body regions and could be developed around the hip and pelvis with the aim of reducing the large variability in imaging parameters and wasted time on pilot research (96).

\section{Measurement}

Previous studies have examined the influence of rater's experience in reading and interpreting MRI $(97,98)$. In this review, radiologists were most frequently cited professionals reading and interpreting results, with some studies specifying musculoskeletal radiologists to reflect greater experience in musculoskeletal presentations. Overall, moderate to excellent reliability was reported across included studies, supporting previous research demonstrating MRI to be reliable for muscle size and fatty infiltrate measures $(6,99)$. One study (73) assessing size measures in a total hip arthroplasty population found poor reliability for measuring gluteus minimus size with analysis limited by prosthesis artifacts and poor visualisation. To overcome this limitation specific MRI techniques have been developed for improving imaging around and near metal (100-102).

\section{Size measures}

Seven single level axial slices were identified that provided consistent CSA measurement, including three for both gluteus maximus and $\mathrm{TFL}$, and four for both gluteus medius and minimus. There was no consensus on which axial slice best represents size and/or location where size changes are most likely to occur. E-12 anatomical plastinates did make visualisation of muscle borders clearer, particularly around neighbouring gluteus medius and piriformis, TFL and gluteus medius and TFL and rectus femoris. The use of E-12 anatomical 
plastinates in understanding and defining muscle borders at certain single level slices can aid future studies to correctly trace muscle borders and could help develop more accurate automatic, machine learning techniques.

Anatomical slice levels used in some of the included studies, where located at the very proximal or distal insertions of the target muscle which may not be representative of the muscle's overall size. For example, the level of the anterior superior iliac spine for gluteus minimus measurement may not be the best representation for size as the muscle may not even appear at this level in some individuals. Interestingly, four studies $(58,103-105)$ reported size measurements from maximum CSA for individual muscles. This is supported by a recent study (106) in healthy individuals, which compared greatest CSA and volume and found a positive correlation for gluteus maximus and gluteus medius muscles. However greatest CSA may be quite different between individuals, pathologies and across studies. It is unclear at what level CSA should be calculated for the lateral hip muscles.

Compared to CSA, volume has a stronger correlation to muscle strength $(12,107)$, power $(108)$, and can better reflect muscle size for the entire muscle in both healthy and musculoskeletal pain populations $(7,12)$. Additionally assessing whole muscle, volume can better identify regions more susceptible to change and can inform most appropriate levels for CSA $(7,109)$. For example in the thigh, after a bout of strength training in healthy individuals, muscle size changes have been observed in proximal portions of a muscle but not around distal portions (110). Single CSA measures may therefore miss potential changes, depending on where measurements are taken. However compared to CSA, volume calculations can be more time consuming when manually derived. Supported by the results of this review, there has been an increase in interest and development of automatic calculations through machine learning. This increase will lead to greater availability of studies for future pooling of data.

\section{Fatty infiltration}

For assessment of fatty infiltration, six axial slice locations were identified including two for TFL, four for each of the gluteal muscles. There was no consensus which axial slice best represents fatty infiltration and/or location where changes are most likely to occur. We found that $86 \%$ of studies measuring fatty infiltration used qualitative, five-point Likert scales, often at a single slice. The most frequent Likert scale used was the Goutellier classification system(41). All studies incorporating quantitative methods for fatty infiltration studies have been published within the last 10 years reflecting it as an emerging technique.

We feel it is important to quantify muscle fat across the entire length of the muscle. This will help to identify locations where muscle fat accumulates in symptomatic groups, how it compares to asymptomatic groups, and where interventions like exercise may have the greatest effect. For example, in a study by Koch et al. (26), muscle fat was quantified on every slice from proximal to distal, and normalised to muscle length. They found that exercise had a significant effect on reducing muscle fat of gluteus minimus at the proximal portion of the muscle. If muscle fat was only measured in the distal portion, then the authors may have falsely concluded that exercise had no effect on muscle fat. In other regions of the body, Crawford and colleagues (111) have shown that the fat content at lumbar segment four (L4) best represents fatty infiltration measures that reflects the entire lumbar region in healthy participants. Further work is needed on the hip muscles to clarify if specific locations are representative of whole muscle changes.

In addition to the specific anatomical level of location, recent cadavar and electromyography studies have identified different anatomical and functional regions within the lateral hip muscles $(30,112,113)$. These compartments or regions within the individual muscle may be uniquely impacted by specific movements or muscle actions, which has relevance in musculoskeletal pathology. For example, some studies in this review divided the gluteus medius and minimus muscles into either three equal parts (anterior, middle and posterior) or two equal parts (anterior/posterior) while the gluteus maximus was divided into upper and lower portions. Investigation and understanding of muscle size and fatty infiltration within these functional regions and portions has the potential to guide future interventional studies. In spinal studies such divisions can allow for a more specific quantification to map the spatial distribution of fat content, which is increasingly showing clinical relevance as a meaningful parameter $(111,114-117)$.

\section{MRI advances}

Manual tracing techniques were used for the majority of size studies but can be time consuming, involving several hours per participant. Recent advances in MRI technology include the development of automated tracing techniques through machine learning (52). Machine learning for muscle tracing as well as for automatic fatty infiltration calculation has shown to be reliable and accurate in other regions (118). Automated analysis incorporating machine learning is more time efficient than manual tracing, reducing analysis time from hours to seconds while still maintaining near human-level performance. However with limited valid and reliable automated methods, manual methods for labelling muscles for size and fatty infiltration are currently the gold standard $(52,85)$. However machine learning has the potential to make the analyses of larger data sets more feasible, increasing the statistical power of future research and 
facilitating the translation of these measures to clinical practice. Although in their infancy, automated, machine learning methods around the lateral hip muscles have shown to provide reliable data for size and the ability to quantify fatty infiltration and will aid future research $(26,48,52,85,94,119,120)$.

\section{Implications}

Establishing a standardised method for the MRI assessment of lateral hip muscles will aid in understanding normal muscle size and fatty infiltration as well as aid the examination of musculoskeletal conditions. This may help further knowledge on disease characteristics, progression of pathology, and muscular response to aging, exercise and injury.

\section{Conclusion}

Whilst no consistency was found for which anatomical location(s) is(are) most appropriate and clinically meaningful to measure lateral hip muscle size and fatty infiltration, we report several identifiable anatomical levels for single axial slice muscle size and fatty infiltration. Further studies into whole muscle measures are required before strong recommendations can be made about the most suitable anatomical locations for standardised MRI single slice muscle measures and within muscle regions susceptible to change. Whilst automated machine learning technology is rapidly emerging with associated improvements in time efficiency, widespread implementation remains a challenge. Accordingly, there remains a need to optimise manual segmentation. Overall, the findings of this scoping review will assist in the future establishment of a standardised method for examination of and measurement for lateral hip musculature using MRI.

\section{Declarations}

\section{Ethics approval and consent to participate}

No ethics approval was required to undertake this descriptive methodological study. The preparation of the E-12 plastinated sections took place in accordance with the New Zealand Human Tissue Act (2008) and University of Otago institutional guidelines.

\section{Consent for publication}

Approval to use images of the E-12 anatomical plastinate sections was granted by the Department of Anatomy, University of Otago. All MRIs were derived from the same informed and consenting adult subject.

\section{Availability of data and materials}

All the data supporting the findings are contained within the manuscript.

\section{Competing interests}

The authors declare that they have no competing interests.

\section{Funding}

ZP is supported by the National Health and Medical Research Council (NHMRC) Postgraduate Scholarship [APP1191009]. The content is solely the responsibility of the authors and does not necessarily represent the official views of the NHMRC.

\section{Authors' Contributions}

Z.P., A.I.S., A.B.M., P.L., J.C., and J.M.E. conceived the study, while J.M.E., K.A.W., N.N.F., J.C., R.J.C. each made substantial contributions to its design. Z.P., N.N.F., C.S. and A.I.S. were involved in screening of results and data extraction.

Z.P., A.I.S., A.B.M., P.L., N.N.F., J.C., and J.M.E. have been involved in drafting the manuscript. All authors have been involved in revising manuscript critically for important intellectual content and each given final approval of the version to be published.

Z.P., A.I.S., A.B.M. and P.L. agree to be accountable for all aspects of the work in ensuring that questions related to the accuracy or integrity of any part of the work are appropriately investigated and resolved.

\section{Acknowledgements}


The authors would like to acknowledge the contribution of Chris Smith, museum curator, W.D. Trotter Anatomy Museum, University of Otago, New Zealand (chris.smith@otago.ac.nz), for his work in preparing the E12 plastinated slices and images for publication.

The authors would like to thank the staff at the Imaging @ Olympic Park and Qscan radiology clinics, who assisted in the collection of MRI images for this study, and all the study participants.

\section{Author information}

${ }^{1}$ La Trobe University, School of Allied Health, Australia ${ }^{2}$ University of Queensland, School of Health and Rehabilitation Sciences, Australia $^{3}$ The University of Otago, Department of Anatomy, School of Biomedical Sciences, New Zealand ${ }^{4}$ The University of Sydney, Sydney School of Health Sciences, Australia ${ }^{5}$ Northwestern University, Department of Physical Therapy and Human Movement Sciences, Feinberg School of Medicine, Chicago, IL, USA ${ }^{6}$ Stanford University, Department of Anesthesiology, Perioperative and Pain Medicine, California, America ${ }^{7}$ Body Urbanist and Consultant, Hünenberg See, Switzerland ${ }^{8}$ The University of Otago, Centre for Early Learning in Medicine, Otago Medical School, New Zealand ${ }^{9}$ Allied Health Research, Northern Health, Epping, Victoria, Australia

\section{References}

1. Dean Deyle G. The role of MRI in musculoskeletal practice: a clinical perspective. Journal of Manual \& Manipulative Therapy. 2011;19(3):152-61.

2. McMahon KL, Cowin G, Galloway G. Magnetic resonance imaging: the underlying principles. journal of orthopaedic \& sports physical therapy. 2011;41(11):806-19.

3. Grover VP, Tognarelli JM, Crossey MM, Cox IJ, Taylor-Robinson SD, McPhail MJ. Magnetic resonance imaging: principles and techniques: lessons for clinicians. Journal of clinical and experimental hepatology. 2015;5(3):246-55.

4. Elessawy SS, Borg MAE-G, Mohamed MAE-S, Elhawary GE, Abd El-Salam EM. The role of MRI in the evaluation of muscle diseases. The Egyptian Journal of Radiology and Nuclear Medicine. 2013;44(3):607-15.

5. Elliott JM, Cornwall J, Kennedy E, Abbott R, Crawford RJ. Towards defining muscular regions of interest from axial magnetic resonance imaging with anatomical cross-reference: part II-cervical spine musculature. BMC musculoskeletal disorders. 2018;19(1):171.

6. Bley TA, Wieben O, François CJ, Brittain JH, Reeder SB. Fat and water magnetic resonance imaging. Journal of Magnetic Resonance Imaging. 2010;31(1):4-18.

7. Pons C, Borotikar B, Garetier M, Burdin V, Ben Salem D, Lempereur M, et al. Quantifying skeletal muscle volume and shape in humans using MRI: a systematic review of validity and reliability. PloS one. 2018;13(11):e0207847.

8. Kemp JL, Schache AG, Makdissi M, Sims KJ, Crossley KM. Greater understanding of normal hip physical function may guide clinicians in providing targeted rehabilitation programmes. Journal of science and medicine in sport. 2013;16(4):292-6.

9. Beck M, Kalhor M, Leunig M, Ganz R. Hip morphology influences the pattern of damage to the acetabular cartilage: femoroacetabular impingement as a cause of early osteoarthritis of the hip. The Journal of bone and joint surgery British volume. 2005;87(7):1012-8.

10. Retchford T, Crossley KM, Grimaldi A, Kemp JL, Cowan SM. Can local muscles augment stability in the hip? A narrative literature review. J Musculoskelet Neuronal Interact. 2013;13(1):1-12.

11. Jones EJ, Bishop PA, Woods AK, Green JM. Cross-sectional area and muscular strength. Sports Medicine. 2008;38(12):987-94.

12. Fukunaga T, Miyatani M, Tachi M, Kouzaki M, Kawakami Y, Kanehisa H. Muscle volume is a major determinant of joint torque in humans. Acta physiologica scandinavica. 2001;172(4):249-55.

13. Correa TA, Crossley KM, Kim HJ, Pandy MG. Contributions of individual muscles to hip joint contact force in normal walking. Journal of biomechanics. 2010;43(8):1618-22.

14. Bergmann G, Deuretzbacher G, Heller M, Graichen F, Rohlmann A, Strauss J, et al. Hip contact forces and gait patterns from routine activities. Journal of biomechanics. 2001;34(7):859-71.

15. Beck M, Sledge JB, Gautier E, Dora CF, Ganz R. The anatomy and function of the gluteus minimus muscle. The Journal of bone and joint surgery British volume. 2000;82(3):358-63.

16. Flack NAMS, Nicholson HD, Woodley SJ. A review of the anatomy of the hip abductor muscles, gluteus medius, gluteus minimus, and tensor fascia lata. Clinical anatomy. 2012;25(6):697-708.

Page $10 / 34$ 
17. Marshall AR, Noronha Md, Zacharias A, Kapakoulakis T, Green R. Structure and function of the abductors in patients with hip osteoarthritis: Systematic review and meta-analysis. Journal Of Back And Musculoskeletal Rehabilitation. 2016;29(2):191-204.

18. Antonio S, Wolfgang G, Robert H, Fullerton B, Carla S. The anatomical and functional relation between gluteus maximus and fascia lata. Journal of bodywork and movement therapies. 2013;17(4):512-7.

19. Cowan RM, Semciw Al, Pizzari T, Cook J, Rixon MK, Gupta G, et al. Muscle Size and Quality of the Gluteal Muscles and Tensor Fasciae Latae in Women with Greater Trochanteric Pain Syndrome. Clinical Anatomy. 2020;33(7):1082-90.

20. Woodley SJ, Nicholson HD, Livingstone V, Doyle TC, Meikle GR, Macintosh JE, et al. Lateral hip pain: findings from magnetic resonance imaging and clinical examination. journal of orthopaedic \& sports physical therapy. 2008;38(6):313-28.

21. Zacharias A, Green RA, Semciw A, English DJ, Kapakoulakis T, Pizzari T. Atrophy of hip abductor muscles is related to clinical severity in a hip osteoarthritis population. Clinical anatomy. 2018;31(4):507-13.

22. Zacharias A, Pizzari T, English D, Kapakoulakis T, Green R. Hip abductor muscle volume in hip osteoarthritis and matched controls. Osteoarthritis and cartilage. 2016;24(10):1727-35.

23. Grimaldi A, Richardson C, Durbridge G, Donnelly W, Darnell R, Hides J. The association between degenerative hip joint pathology and size of the gluteus maximus and tensor fascia lata muscles. Manual Therapy. 2009;14(6):611-7.

24. Grimaldi A, Richardson C, Stanton W, Durbridge G, Donnelly W, Hides J. The association between degenerative hip joint pathology and size of the gluteus medius, gluteus minimus and piriformis muscles. Manual Therapy. 2009;14(6):605-10.

25. Malloy P, Stone AV, Kunze KN, Neal WH, Beck EC, Nho SJ. Patients with unilateral femoroacetabular impingement syndrome have asymmetrical hip muscle cross-sectional area and compensatory muscle changes associated with preoperative pain level. Arthroscopy: The Journal of Arthroscopic \& Related Surgery. 2019;35(5):1445-53.

26. Koch K, Semciw Al, Commean PK, Hillen TJ, Fitzgerald GK, Clohisy JC, et al. Comparison between movement pattern training and strengthening on muscle volume, muscle fat, and strength in patients with hip-related groin pain: An exploratory analysis. Journal of Orthopaedic Research®. 2021.

27. O'leary S, Jull G, Van Wyk L, Pedler A, Elliott J. Morphological changes in the cervical muscles of women with chronic whiplash can be modified with exercise-a pilot study. Muscle \& nerve. 2015;52(5):772-9.

28. Marcus R, Addison O, Kidde J, Dibble L, Lastayo P. Skeletal muscle fat infiltration: impact of age, inactivity, and exercise. The journal of nutrition, health \& aging. 2010;14(5):362-6.

29. Lawrenson P, Crossley K, Vicenzino B, Hodges P, James G, Croft K, et al. Muscle size and composition in people with articular hip pathology: a systematic review with meta-analysis. Osteoarthritis and cartilage. 2019;27(2):181-95.

30. Flack N, Nicholson H, Woodley S. The anatomy of the hip abductor muscles. Clinical anatomy. 2014;27(2):241-53.

31. Crawford RJ, Cornwall J, Abbott R, Elliott JM. Manually defining regions of interest when quantifying paravertebral muscles fatty infiltration from axial magnetic resonance imaging: a proposed method for the lumbar spine with anatomical cross-reference. BMC musculoskeletal disorders. 2017;18(1):1-11.

32. Ottone NE, Baptista CA, Latorre R, Bianchi HF, Del Sol M, Fuentes R. E12 sheet plastination: Techniques and applications. Clinical Anatomy. 2018;31(5):742-56.

33. Munn Z, Peters MDJ, Stern C, Tufanaru C, McArthur A, Aromataris E. Systematic review or scoping review? Guidance for authors when choosing between a systematic or scoping review approach. BMC Medical Research Methodology. 2018;18(1):143.

34. Tricco AC, Lillie E, Zarin W, O'Brien KK, Colquhoun H, Levac D, et al. PRISMA Extension for Scoping Reviews (PRISMA-ScR): Checklist and Explanation. Ann Intern Med. 2018;169(7):467-73.

35. Smith MMF, Elliott JM, Al-Najjar A, Weber KA, Hoggarth MA, Vicenzino B, et al. New insights into intrinsic foot muscle morphology and composition using ultra-high-field (7-Tesla) magnetic resonance imaging. BMC Musculoskeletal Disorders. 2021;22(1):1-14.

36. Peters MDJ GC, Mclnerney P, Munn Z, Tricco AC, Khalil, H. Chapter 11: Scoping Reviews. In: Aromataris E MZ, editor. Joanna Briggs Institute Reviewer's Manual: Joanna Briggs Institute; 2020. p. https://reviewersmanual.joannabriggs.org/.

37. Marx RG, Wilson SM, Swiontkowski MF. Updating the assignment of levels of evidence. LWW; 2015.

38. Bartko JJ. The intraclass correlation coefficient as a measure of reliability. Psychological reports. 1966;19(1):3-11.

39. Chmura Kraemer H, Periyakoil VS, Noda A. Kappa coefficients in medical research. Statistics in medicine. 2002;21(14):2109-29.

40. McHugh ML. Interrater reliability: the kappa statistic. Biochemia medica. 2012;22(3):276-82. 
41. Goutallier D, Postel J-M, Bernageau J, Lavau L, Voisin M-C. Fatty muscle degeneration in cuff ruptures. Pre-and postoperative evaluation by CT scan. Clinical orthopaedics and related research. 1994(304):78-83.

42. Engelken F, Wassilew GI, Köhlitz T, Brockhaus S, Hamm B, Perka C, et al. Assessment of Fatty Degeneration of the Gluteal Muscles in Patients With THA Using MRI: Reliability and Accuracy of the Goutallier and Quartile Classification Systems. Journal of Arthroplasty. 2014;29(1):149-53.

43. Jaegers S, Dantuma R, de Jongh HJ. Three-dimensional reconstruction of the hip muscles on the basis of magnetic resonance images. Surg Radiol Anat. 1992;14(3):241-9.

44. Kheterpal AB, Harvey JP, Husseini JS, Martin SD, Torriani M, Bredella MA. Hip abductor tears in ischiofemoral impingement. Skeletal Radiology. 2020;49(11):1747-52.

45. Mendis MD, Wilson SJ, Hayes DA, Hides JA. Hip muscle atrophy in patients with acetabular labral joint pathology. Clinical Anatomy. 2020;33(4):538-44.

46. Peiris WL, Cicuttini FM, Constantinou M, Yaqobi A, Hussain SM, Wluka AE, et al. Association between hip muscle cross-sectional area and hip pain and function in individuals with mild-to-moderate hip osteoarthritis: a cross-sectional study. BMC musculoskeletal disorders. 2020;21:1-7.

47. Zhao G, Zhu R, Jiang S, Xu N, Bao H, Wang Y. Using the anterior capsule of the hip joint to protect the tensor fascia lata muscle during direct anterior total hip arthroplasty: a randomized prospective trial. BMC musculoskeletal disorders. 2020;21(1):1-10.

48. Vasarhelyi EM, Williams HA, Howard JL, Petis S, Barfett J, Lanting BA. The Effect of Total Hip Arthroplasty Surgical Technique on Postoperative Muscle Atrophy. Orthopedics. 2020;43(6):361-6.

49. Ruckenstuhl P, Wassilew GI, Muller M, Hipfl C, Pumberger M, Perka C, et al. Functional assessment and patient-related outcomes after gluteus maximus flap transfer in patients with severe hip abductor deficiency. Journal of Clinical Medicine. 2020;9(6):1-12.

50. Miller R, Balshaw TG, Massey GJ, Maeo S, Lanza MB, Johnston M, et al. The Muscle Morphology of Elite Sprint Running. Medicine \& Science in Sports \& Exercise. 2021;53(4):804-15.

51. Dorado C, Lopez-Gordillo A, Serrano-Sanchez JA, Calbet JAL, Sanchis-Moysi J. Hypertrophy of Lumbopelvic Muscles in Inactive Women: A 36-Week Pilates Study. Sports health. 2020;12(6):547-51.

52. Belzunce MA, Henckel J, Fotiadou A, Di Laura A, Hart A. Automated multi-atlas segmentation of gluteus maximus from Dixon and T1-weighted magnetic resonance images. Magnetic Resonance Materials in Physics, Biology and Medicine. 2020:1-12.

53. Belzunce MA, Henckel J, Fotiadou A, Di Laura A, Hart A. Automated measurement of fat infiltration in the hip abductors from Dixon magnetic resonance imaging. Magnetic Resonance Imaging. 2020;72:61-70.

54. Burian E, Syvari J, Dieckmeyer M, Holzapfel C, Drabsch T, Sollmann N, et al. Age- and BMI-related variations of fat distribution in sacral and lumbar bone marrow and their association with local muscle fat content. Scientific reports. 2020;10(1):9686.

55. Montefiori E, Kalkman BM, Henson WH, Paggiosi MA, McCloskey EV, Mazzà C. MRI-based anatomical characterisation of lowerlimb muscles in older women. PloS one. 2020;15(12):e0242973.

56. Mendis MD, Hides JA. Effect of motor control training on hip muscles in elite football players with and without low back pain. Journal of science and medicine in sport. 2016;19(11):866-71.

57. Skorupska E, Keczmer P, Łochowski RM, Tomal P, Rychlik M, Samborski W. Reliability of MR-based volumetric 3-D analysis of pelvic muscles among subjects with low back with leg pain and healthy volunteers. PLoS One. 2016;11(7):e0159587.

58. Ackland D, Denton M, Schache A, Pandy M, Crossley K. Hip abductor muscle volumes are smaller in individuals affected by patellofemoral joint osteoarthritis. Osteoarthritis and cartilage. 2019;27(2):266-72.

59. Kivle K, Lindland E, Mjaaland K, Pripp A, Svenningsen S, Nordsletten L. The gluteal muscles in end-stage osteoarthritis of the hip: intra-and interobserver reliability and agreement of MRI assessments of muscle atrophy and fatty degeneration. Clinical radiology. 2018;73(7):675. e17-. e24.

60. Agten C, Sutter R, Dora C, Pfirrmann C, Agten CA, Pfirrmann CWA. MR imaging of soft tissue alterations after total hip arthroplasty: comparison of classic surgical approaches. European Radiology. 2017;27(3):1312-21.

61. Pfirrmann CW, Notzli HP, Dora C, Hodler J, Zanetti M. Abductor tendons and muscles assessed at MR imaging after total hip arthroplasty in asymptomatic and symptomatic patients. Radiology. 2005;235(3):969-76.

62. Rodríguez-Roiz JM, Bori G, Tomas X, Fernández-Valencia JA, García-Díez Al, Pomés J, et al. Hypertrophy of the tensor fascia lata muscle as a complication of total hip arthroplasty. European Journal of Orthopaedic Surgery \& Traumatology. 2017;27(2):255-9.

Page 12/34 
63. Ebert JR, Smith A, Breidahl W, Fallon M, Janes GC. Association of preoperative gluteal muscle fatty infiltration with patient outcomes in women after hip abductor tendon repair augmented with LARS. The American journal of sports medicine. 2019;47(13):3148-57.

64. Chi A, Long S, Zoga A, Read P, Deely D, Parker L, et al. Prevalence and pattern of gluteus medius and minimus tendon pathology and muscle atrophy in older individuals using MRI. Skeletal Radiology. 2015;44(12):1727-33.

65. Flack NAMS, Meikle G, Reddy M, Nicholson H, Woodley S. Hip abductor muscle volume in women with lateral hip pain: a casecontrolled study. Surgical and Radiologic Anatomy. 2012:1-9.

66. Kim HK, Serai S, Merrow AC, Wang L, Horn PS, Laor T. Objective measurement of minimal fat in normal skeletal muscles of healthy children using T2 relaxation time mapping (T2 maps) and MR spectroscopy. Pediatr Radiol. 2014;44(2):149-57.

67. Kawasaki M, Hasegawa Y, Okura T, Ochiai S, Fujibayashi T. Muscle damage after total hip arthroplasty through the direct anterior approach for developmental dysplasia of the hip. The Journal of arthroplasty. 2017;32(8):2466-73.

68. Loureiro A, Constantinou M, Diamond LE, Beck B, Barrett R. Individuals with mild-to-moderate hip osteoarthritis have lower limb muscle strength and volume deficits. BMC musculoskeletal disorders. 2018;19(1):1-9.

69. Mendis MD, Wilson SJ, Hayes DA, Watts MC, Hides JA. Hip flexor muscle size, strength and recruitment pattern in patients with acetabular labral tears compared to healthy controls. Manual therapy. 2014;19(5):405-10.

70. Miokovic T, Armbrecht G, Felsenberg D, Belavý DL. Differential atrophy of the postero-lateral hip musculature during prolonged bedrest and the influence of exercise countermeasures. Journal of Applied Physiology. 2011;110(4):926-34.

71. Masuda K, Kikuhara N, Takahashi H, Yamanaka K. The relationship between muscle cross-sectional area and strength in various isokinetic movements among soccer players. Journal of Sports Sciences. 2003;21(10):851-8.

72. Takahashi K, Wakahara T. Association between trunk and gluteus muscle size and long jump performance. PloS one. 2019;14(11):e0225413.

73. Springer I, Müller M, Hamm B, Dewey M. Intra- and interobserver variability of magnetic resonance imaging for quantitative assessment of abductor and external rotator muscle changes after total hip arthroplasty. European Journal of Radiology. 2012;81(5):928-33.

74. Takada R, Jinno T, Miyatake K, Hirao M, Kimura A, Koga D, et al. Direct anterior versus anterolateral approach in one-stage supine total hip arthroplasty. Focused on nerve injury: A prospective, randomized, controlled trial. Journal of Orthopaedic Science. 2018;23(5):783-7.

75. Takada R, Jinno T, Miyatake K, Hirao M, Yoshii T, Okawa A. Incidence of tensor fascia lata muscle atrophy after using the modified Watson-Jones anterolateral approach in total hip arthroplasty. European Journal of Orthopaedic Surgery \& Traumatology. 2021;31(3):533-40.

76. Arokoski MH, Arokoski JP, Haara M, Kankaanpää M, Vesterinen M, Niemitukia LH, et al. Hip muscle strength and muscle cross sectional area in men with and without hip osteoarthritis. The Journal of rheumatology. 2002;29(10):2185-95.

77. Yang F, Mamtimin M, Duan Y-P, Sun H, Xu Y, Zhang X, et al. Volume of Gluteus Maximus and Minimus Increases After Hip Arthroscopy for Femoroacetabular Impingement Syndrome. Arthroscopy: The Journal of Arthroscopy \& Related Surgery. 2021;37(3):862-70.

78. Yasuda T, Fukumura K, Fukuda T, Uchida Y, lida H, Meguro M, et al. Muscle size and arterial stiffness after blood flow-restricted low-intensity resistance training in older adults. Scandinavian journal of medicine \& science in sports. 2014;24(5):799-806.

79. Sutter R, Kalberer F, Binkert CA, Graf N, Pfirrmann CW, Gutzeit A. Abductor tendon tears are associated with hypertrophy of the tensor fasciae latae muscle. Skeletal radiology. 2013;42(5):627-33.

80. Emery S, Cook J, Ferris AR, Smith P, Mayes S. Hip flexor muscle size in ballet dancers compared to athletes, and relationship to hip pain. Phys Ther Sport. 2019;38:146-51.

81. Unis DB, Hawkins EJ, Alapatt MF, Benitez CL. Postoperative changes in the tensor fascia lata muscle after using the modified anterolateral approach for total hip arthroplasty. The Journal of arthroplasty. 2013;28(4):663-5.

82. Tesch PA, Berg HE, Bring D, Evans HJ, LeBlanc AD. Effects of 17-day spaceflight on knee extensor muscle function and size. European journal of applied physiology. 2005;93(4):463-8.

83. Marcon M, Berger N, Manoliu A, Fischer M, Nanz D, Andreisek G, et al. Normative values for volume and fat content of the hip abductor muscles and their dependence on side, age and gender in a healthy population. Skeletal Radiology. 2016;45(4):465-74. 
84. Bravo S, Lowndes J, Sinnett S, Yu Z, Rippe J. Consumption of sucrose and high-fructose corn syrup does not increase liver fat or ectopic fat deposition in muscles. Appl Physiol Nutr Metab. 2013;38(6):681-8.

85. Belzunce MA, Henckel J, Di Laura A, Hart A. Intramuscular fat in gluteus maximus for different levels of physical activity. Scientific reports. 2021;11(1):1-10.

86. Rykov K, Meys TWGM, Knobben BAS, Sietsma MS, Reininga IHF, ten Have BLEF. MRI Assessment of Muscle Damage After the Posterolateral Versus Direct Anterior Approach for THA (Polada Trial). A Randomized Controlled Trial. Journal of Arthroplasty. 2021;36(9):3248-

87. Bremer A, Kalberer F, Pfirrmann C, Dora C. Soft-tissue changes in hip abductor muscles and tendons after total hip replacement: comparison between the direct anterior and the transgluteal approaches. The Journal of bone and joint surgery British volume. 2011;93(7):886-9.

88. De Anta-Díaz B, Serralta-Gomis J, Lizaur-Utrilla A, Benavidez E, López-Prats FA. No differences between direct anterior and lateral approach for primary total hip arthroplasty related to muscle damage or functional outcome. International Orthopaedics. 2016;40(10):2025-30.

89. Kovalak E, Özdemir H, Ermutlu C, Obut A. Assessment of hip abductors by MRI after total hip arthroplasty and effect of fatty atrophy on functional outcome. Acta orthopaedica et traumatologica turcica. 2018;52(3):196-200.

90. Müller M, Tohtz S, Dewey M, Springer I, Perka C. Evidence of reduced muscle trauma through a minimally invasive anterolateral approach by means of MRI. Clinical Orthopaedics and Related Research®. 2010;468(12):3192-200.

91. Müller M, Tohtz S, Dewey M, Springer I, Perka C. Age-related appearance of muscle trauma in primary total hip arthroplasty and the benefit of a minimally invasive approach for patients older than 70 years. International orthopaedics. 2011;35(2):165-71.

92. Müller M, Tohtz S, Springer I, Dewey M, Perka C. Randomized controlled trial of abductor muscle damage in relation to the surgical approach for primary total hip replacement: minimally invasive anterolateral versus modified direct lateral approach. Archives Of Orthopaedic And Trauma Surgery. 2011;131(2):179-89.

93. Von Roth P, Abdel M, Wauer F, Winkler T, Wassilew G, Diederichs G, et al. Significant muscle damage after multiple revision total hip replacements through the direct lateral approach. The bone \& joint journal. 2014;96(12):1618-22.

94. Winkler T, Perka C, von Roth P, Agres AN, Plage H, Preininger B, et al. Immunomodulatory placental-expanded, mesenchymal stromal cells improve muscle function following hip arthroplasty. Journal of cachexia, sarcopenia and muscle. 2018;9(5):880-97.

95. Thaunat M, Clowez G, Desseaux A, Murphy CG, Sbiyaa M, Noël E, et al. Influence of muscle fatty degeneration on functional outcomes after endoscopic gluteus medius repair. Arthroscopy: The Journal of Arthroscopic \& Related Surgery. 2018;34(6):181624.

96. Cohen-Adad J, Alonso-Ortiz E, Abramovic M, Arneitz C, Atcheson N, Barlow L, et al. Generic acquisition protocol for quantitative MRI of the spinal cord. Nature protocols. 2021:1-22.

97. Mhuiris ÁN, Volken T, Elliott JM, Hoggarth M, Samartzis D, Crawford RJ. Reliability of quantifying the spatial distribution of fatty infiltration in lumbar paravertebral muscles using a new segmentation method for T1-weighted MRI. BMC musculoskeletal disorders. 2016;17(1):1-7.

98. Valentin S, Yeates TD, Licka T, Elliott J. Inter-rater reliability of trunk muscle morphometric analysis. Journal of back and musculoskeletal rehabilitation. 2015;28(1):181-90.

99. Smith AC, Parrish TB, Abbott R, Hoggarth MA, Mendoza K, Chen YF, et al. Muscle-fat MRI: 1.5 tesla and 3.0 tesla versus histology. Muscle \& nerve. 2014;50(2):170-6.

100. Choi SJ, Koch KM, Hargreaves BA, Stevens KJ, Gold GE. Metal artifact reduction with MAVRIC SL at 3-T MRI in patients with hip arthroplasty. AJR Am J Roentgenol. 2015;204(1):140-7.

101. Gutierrez LB, Do BH, Gold GE, Hargreaves BA, Koch KM, Worters PW, et al. MR imaging near metallic implants using MAVRIC SL: initial clinical experience at 3T. Acad Radiol. 2015;22(3):370-9.

102. Koch KM, King KF, Carl M, Hargreaves BA. Imaging near metal: The impact of extreme static local field gradients on frequency encoding processes. Magn Reson Med. 2014;71(6):2024-34.

103. Amabile C, Moal B, Chtara OA, Pillet H, Raya JG, lannessi A, et al. Estimation of spinopelvic muscles' volumes in young asymptomatic subjects: a quantitative analysis. Surgical and Radiologic Anatomy. 2017;39(4):393-403.

104. Handsfield GG, Meyer CH, Hart JM, Abel MF, Blemker SS. Relationships of 35 lower limb muscles to height and body mass quantified using MRI. Journal of biomechanics. 2014;47(3):631-8.

Page $14 / 34$ 
105. Sugisaki N, Kobayashi K, Tsuchie H, Kanehisa H. Associations between individual lower-limb muscle volumes and 100-m sprint time in male sprinters. International journal of sports physiology and performance. 2018;13(2):214-9.

106. Homma D, Minato I, Imai N, Miyasaka D, Sakai Y, Horigome Y, et al. Investigation on the measurement sites of the cross-sectional areas of the gluteus maximus and gluteus medius. Surg Radiol Anat. 2019;41(1):109-15.

107. Akagi R, Takai Y, Ohta M, Kanehisa H, Kawakami Y, Fukunaga T. Muscle volume compared to cross-sectional area is more appropriate for evaluating muscle strength in young and elderly individuals. Age and ageing. 2009;38(5):564-9.

108. O’Brien TD, Reeves ND, Baltzopoulos V, Jones DA, Maganaris CN. Strong relationships exist between muscle volume, joint power and whole-body external mechanical power in adults and children. Experimental Physiology. 2009;94(6):731-8.

109. Boom H, Van Spronsen P, Van Ginkel F, Van Schijndel R, Castelijns J, Tuinzing D. A comparison of human jaw muscle crosssectional area and volume in long-and short-face subjects, using MRI. archives of oral biology. 2008;53(3):273-81.

110. Hudelmaier M, Wirth W, Himmer M, Ring-Dimitriou S, Sänger A, Eckstein F. Effect of exercise intervention on thigh muscle volume and anatomical cross-sectional areas-Quantitative assessment using MRI. Magnetic resonance in medicine. 2010;64(6):171320.

111. Crawford RJ, Filli L, Elliott J, Nanz D, Fischer M, Marcon M, et al. Age-and level-dependence of fatty infiltration in lumbar paravertebral muscles of healthy volunteers. American Journal of Neuroradiology. 2016;37(4):742-8.

112. Semciw Al, Green RA, Pizzari T, Briggs C. Verification of a standardized method for inserting intramuscular EMG electrodes into uniquely oriented segments of gluteus minimus and gluteus medius. Clinical anatomy. 2013;26(2):244-52.

113. Al-Hayani A. The functional anatomy of hip abductors. Folia morphologica. 2009;68(2):98-103.

114. Crawford RJ, Volken T, Mhuiris ÁN, Bow CC, Elliott JM, Hoggarth MA, et al. Geography of lumbar paravertebral muscle fatty infiltration: The influence of demographics, low back pain, and disability. Spine. 2019;44(18):1294-302.

115. D'hooge R, Cagnie B, Crombez G, Vanderstraeten G, Dolphens M, Danneels L. Increased intramuscular fatty infiltration without differences in lumbar muscle cross-sectional area during remission of unilateral recurrent low back pain. Manual therapy. 2012;17(6):584-8.

116. Abbott R, Pedler A, Sterling M, Hides J, Murphey T, Hoggarth M, et al. The geography of fatty infiltrates within the cervical multifidus and semispinalis cervicis in individuals with chronic whiplash-associated disorders. journal of orthopaedic \& sports physical therapy. 2015;45(4):281-8.

117. Elliott JM, Smith AC, Hoggarth MA, Albin SR, Weber KA, Haager M, et al. Muscle fat infiltration following whiplash: A computed tomography and magnetic resonance imaging comparison. PloS one. 2020;15(6):e0234061.

118. Weber KA, Smith AC, Wasielewski M, Eghtesad K, Upadhyayula PA, Wintermark M, et al. Deep learning convolutional neural networks for the automatic quantification of muscle fat infiltration following whiplash injury. Scientific reports. 2019;9(1):1-8.

119. Klemt C, Simeone FJ, Melnic CM, Tirumala V, Xiong L, Kwon Y-M. MARS MRI assessment of fatty degeneration of the gluteal muscles in patients with THA: reliability and accuracy of commonly used classification systems. Skeletal Radiology. 2021;50(4):665-72.

120. Tran V, De Martino E, Hides J, Cable G, Elliott JM, Hoggarth M, et al. Gluteal Muscle Atrophy and Increased Intramuscular Lipid Concentration Are Not Mitigated by Daily Artificial Gravity Following 60-Day Head-Down Tilt Bed Rest. Frontiers in Physiology. 2021;12(1945).

121. Berber R, Khoo M, Cook E, Guppy A, Hua J, Miles J, et al. Muscle atrophy and metal-on-metal hip implants: a serial MRI study of 74 hips. Acta Orthopaedica. 2015;86(3):351-7.

122. Gerber JP, Marcus RL, Dibble LE, Greis PE, Burks RT, LaStayo PC. Effects of early progressive eccentric exercise on muscle structure after anterior cruciate ligament reconstruction. JBJS. 2007;89(3):559-70.

123. Jaegers S, Arendzen JH, de Jongh HJ. Changes in hip muscles after above-knee amputation. Clinical orthopaedics and related research. 1995(319):276-84.

124. Kiyoshige $Y$, Watanabe E. Fatty degeneration of gluteus minimus muscle as a predictor of falls. Archives of gerontology and geriatrics. 2015;60(1):59-61.

125. Kubo K, Ikebukuro T, Yata H. Effects of squat training with different depths on lower limb muscle volumes. European journal of applied physiology. 2019;119(9):1933-42.

126. Makridis K, Lequesne M, Bard H, Djian P. Clinical and MRI results in 67 patients operated for gluteus medius and minimus tendon tears with a median follow-up of 4.6 years. Orthopaedics \& Traumatology: Surgery \& Research. 2014;100(8):849 - 53.

Page 15/34 
127. Mastenbrook MJ, Commean PK, Hillen TJ, Salsich GB, Meyer GA, Mueller MJ, et al. Hip abductor muscle volume and strength differences between women with chronic hip joint pain and asymptomatic controls. journal of orthopaedic \& sports physical therapy. 2017;47(12):923-30.

128. Müller M, Tohtz S, Dewey M, Springer I, Perka C. Age-related appearance of muscle trauma in primary total hip arthroplasty and the benefit of a minimally invasive approach for patients older than 70 years. International Orthopaedics. 2011;35(2):165-71.

129. Niinimaki S, Harkonen L, Nikander R, Abe S, Knusel C, Sievanen H. The cross-sectional area of the gluteus maximus muscle varies according to habitual exercise loading: Implications for activity-related and evolutionary studies. Homo. 2016;67(2):125-37.

130. Niinimaki S, Narra N, Harkonen L, Abe S, Nikander R, Hyttinen J, et al. Do bone geometric properties of the proximal femoral diaphysis reflect loading history, muscle properties, or body dimensions? Am J Human Biol. 2019;31(4):e23246.

131. Reito A, Elo P, Nieminen J, Puolakka T, Eskelinen A. Gluteal muscle fatty atrophy is not associated with elevated blood metal ions or pseudotumors in patients with a unilateral metal-on-metal hip replacement. Acta orthopaedica. 2016;87(1):29-35.

132. Rothwell DT, Williams DJ, Furlong LM. Measuring muscle size and symmetry in healthy adult males using a time-efficient analysis of magnetic resonance images. Physiol Meas. 2019;40(6):064005.

133. Sakamaki M, Bemben MG, Abe T. Legs and trunk muscle hypertrophy following walk training with restricted leg muscle blood flow. Journal of sports science \& medicine. 2011;10(2):338.

134. Semciw Al, Green RA, Pizzari T. Gluteal muscle function and size in swimmers. Journal of Science \& Medicine in Sport. 2016;19(6):498-503.

135. Yüksel HY, YImaz S, Aksahin E, Çelebi L, Duran S, Muratl HH, et al. The evaluation of hip muscles in patients treated with one-stage combined procedure for unilateral developmental dysplasia of the hip: part I: MRI evaluation. Journal of Pediatric Orthopaedics. 2009;29(8):872-8.

136. Smith MMF, Bonacci J, Mendis MD, Christie C, Rotstein A, Hides JA. Gluteus medius activation during running is a risk factor for season hamstring injuries in elite footballers. Journal of science and medicine in sport. 2017;20(2):159-63.

\section{Tables}

Table 1 MRI parameters for individual studies 


\begin{tabular}{|c|c|c|c|c|c|c|c|c|}
\hline Citation & $\begin{array}{l}\text { Field } \\
\text { Strength } \\
\text { (Tesla) }\end{array}$ & $\begin{array}{l}\text { Axial MRI } \\
\text { Sequence }\end{array}$ & $\begin{array}{l}\text { Slice } \\
\text { thickness } \\
\text { Gap } \\
(\mathrm{mm})\end{array}$ & $\begin{array}{l}\text { MRI slice } \\
\text { selection } \\
\text { range }\end{array}$ & $\begin{array}{l}\text { Muscle } \\
\text { of } \\
\text { interest }\end{array}$ & $\begin{array}{l}\text { Size } \\
\text { measures }\end{array}$ & $\begin{array}{l}\text { Fat } \\
\text { detection }\end{array}$ & $\begin{array}{l}\text { Reliability } \\
\text { (Kappa } \\
\text { Score/ } \\
\text { ICC) }\end{array}$ \\
\hline $\begin{array}{l}\text { Ackland et al., } \\
2019(58)\end{array}$ & 3 & $\begin{array}{l}\text { T2- FS } \\
\text { (water } \\
\text { excitation) } \\
\cdot \text { MEDIC }\end{array}$ & $\begin{array}{l}1 \\
N R\end{array}$ & $\begin{array}{l}\text { Sacral } \\
\text { promontory } \\
\text { to the } \\
\text { inferior } \\
\text { aspect of } \\
\text { the pubic } \\
\text { arch } \\
\text { ( 200 } \\
\text { slices) }\end{array}$ & $\begin{array}{l}\text { TFL } \\
\text { Gmed } \\
\text { Gmin }\end{array}$ & $\checkmark$ & & $\begin{array}{l}\text { Intra- } \\
\text { rater } \\
\text { ICC: } \\
0.997- \\
1.00\end{array}$ \\
\hline $\begin{array}{l}\text { Agten et al., } \\
2017(60)\end{array}$ & 1.5 & $\begin{array}{l}\text { - STIR \& } \\
\text { optimized } \\
\text { inversion } \\
\text { pulse } \\
\text { - T1 }\end{array}$ & $\begin{array}{l}7 \& 6 \\
0\end{array}$ & NR & $\begin{array}{l}\text { TFL } \\
\text { Gmax } \\
\text { Gmed } \\
\text { Gmin }\end{array}$ & & $\checkmark$ & $\begin{array}{l}\text { Inter- } \\
\text { rater } \\
\text { k=0.548 }\end{array}$ \\
\hline $\begin{array}{l}\text { Amabile et al., } \\
2017 \text { (103) }\end{array}$ & 1.5 & - T1 TSE & $\begin{array}{l}5 \\
0\end{array}$ & $\begin{array}{l}\text { Sacrum (S1) } \\
\text { to femoral } \\
\text { condyles }\end{array}$ & $\begin{array}{l}\text { TFL } \\
\text { Gmax } \\
\text { Gmed } \\
\text { GMin }\end{array}$ & $\checkmark$ & & NA \\
\hline $\begin{array}{l}\text { Arokoski et al., } \\
2002(76)\end{array}$ & 1.5 & - T1 TSE & NR & NR & $\begin{array}{l}\text { TFL } \\
\text { Gmax } \\
\text { Gmed } \\
\text { Gmin }\end{array}$ & $\checkmark$ & & NA \\
\hline $\begin{array}{l}\text { Belzunce et al., } \\
2020 \text { a (52) }\end{array}$ & 3 & $\begin{array}{l}\cdot \text { T1 TSE } \\
\cdot \text { DIXON }\end{array}$ & $\begin{array}{l}1.5 \\
0.45\end{array}$ & $\begin{array}{l}3 \mathrm{~cm} \text { below } \\
\text { the lesser } \\
\text { trochanter to } \\
\text { the top of } \\
\text { the iliac } \\
\text { crest }\end{array}$ & Gmax & $\checkmark$ & & NA \\
\hline $\begin{array}{l}\text { Belzunce et al., } \\
2020 \text { b(53) }\end{array}$ & 3 & $\begin{array}{l}\cdot \text { T1 TSE } \\
\cdot \text { DIXON }\end{array}$ & $\begin{array}{l}1.5 \& 3 \\
1.95 \& \\
3.3\end{array}$ & Pelvis & $\begin{array}{l}\text { TFL } \\
\text { Gmax } \\
\text { Gmed } \\
\text { Gmin }\end{array}$ & & $\checkmark$ & NA \\
\hline $\begin{array}{l}\text { Belzunce et al., } \\
2021(85)\end{array}$ & 3 & - DIXON & $\begin{array}{l}1.5 \\
1.95\end{array}$ & $\begin{array}{l}1 \mathrm{~cm} \text { below } \\
\text { the lesser } \\
\text { trochanter to } \\
\text { the top of } \\
\text { the iliac } \\
\text { crest }\end{array}$ & Gmax & $\checkmark$ & $\checkmark$ & NA \\
\hline Berber et al., 2015(121) & NA & $\begin{array}{l}\cdot \text { T1 TSE } \\
\text { - T2 TSE }\end{array}$ & NR & NR & $\begin{array}{l}\text { Gmax } \\
\text { Gmed } \\
\text { Gmin }\end{array}$ & & $\checkmark$ & $\begin{array}{l}\text { Intra- } \\
\text { rater } \\
k=0.463\end{array}$ \\
\hline Bravo et al., 2013(84) & 1.5 & $\cdot \mathrm{T} 1$ & $\begin{array}{l}5 \\
0\end{array}$ & NR & Gmax & & $\checkmark$ & NA \\
\hline Bremer et al., 2011(87) & 1.5 & - T1 SE & NR & NR & $\begin{array}{l}\text { TFL } \\
\text { Gmed } \\
\text { Gmin }\end{array}$ & & $\checkmark$ & NA \\
\hline Burian et al., 2020(54) & 3 & - MEDIC & $\begin{array}{l}1.5 \\
N R\end{array}$ & $\begin{array}{l}\text { Gluteal } \\
\text { region }\end{array}$ & Gmax & & $\checkmark$ & NA \\
\hline Chi et al., 2015(64) & 1.5 & - T1 SE & $\begin{array}{l}4-5 \\
1\end{array}$ & $\begin{array}{l}\text { ASIS to the } \\
\text { ischia }\end{array}$ & $\begin{array}{l}\text { Gmed } \\
\text { Gmin }\end{array}$ & & $\checkmark$ & NA \\
\hline
\end{tabular}




\begin{tabular}{|c|c|c|c|c|c|c|c|c|}
\hline & & $\begin{array}{l}\text { - T2- FSE } \\
\text { fat- } \\
\text { saturated }\end{array}$ & & $\begin{array}{l}\text { (including } \\
\text { both hips) }\end{array}$ & & & & \\
\hline \multirow[t]{2}{*}{ Cowan et al., 2019(19) } & \multirow[t]{2}{*}{3} & $\cdot \mathrm{T} 1$ & 4 & \multirow{2}{*}{$\begin{array}{l}\text { Top of the } \\
\text { iliac crest to } \\
\text { the lesser } \\
\text { trochanter }\end{array}$} & \multirow{2}{*}{$\begin{array}{l}\text { TFL } \\
\text { Gmax } \\
\text { Gmed } \\
\text { Gmin }\end{array}$} & \multirow[t]{2}{*}{$\checkmark$} & \multirow[t]{2}{*}{$\checkmark$} & \multirow{2}{*}{$\begin{array}{l}\text { Intra- } \\
\text { rater } \\
\mathrm{ICC}= \\
0.999\end{array}$} \\
\hline & & $\begin{array}{l}\text { - PD- with } \\
\text { and } \\
\text { without fat } \\
\text { saturation }\end{array}$ & NR & & & & & \\
\hline \multirow{2}{*}{$\begin{array}{l}\text { De Anta-Diaz et al., } \\
\text { 2016(88) }\end{array}$} & \multirow[t]{2}{*}{1.5} & - T1 SE & $3-4$ & \multirow[t]{2}{*}{ NR } & \multirow{2}{*}{$\begin{array}{l}\text { TFL } \\
\text { Gmax } \\
\text { Gmed } \\
\text { Gmin }\end{array}$} & & \multirow[t]{2}{*}{$\checkmark$} & \multirow[t]{2}{*}{ NA } \\
\hline & & $\cdot \mathrm{STIR}$ & NR & & & & & \\
\hline \multirow[t]{3}{*}{ Dorado et al., 2020(51) } & \multirow[t]{3}{*}{1.5} & \multirow[t]{3}{*}{$\cdot \mathrm{NR}$} & 8 & \multirow{3}{*}{$\begin{array}{l}\text { Trunk and } \\
\text { pelvis }\end{array}$} & Gmax & \multirow[t]{3}{*}{$\checkmark$} & & \multirow[t]{3}{*}{ NA } \\
\hline & & & 2 & & Gmed & & & \\
\hline & & & & & Gmin & & & \\
\hline \multirow[t]{2}{*}{ Ebert et al., 2019(63) } & \multirow[t]{2}{*}{$\begin{array}{l}1.5 \\
3\end{array}$} & \multirow[t]{2}{*}{$\begin{array}{l}\text { - T2 fat- } \\
\text { saturated }\end{array}$} & 3.5 & \multirow[t]{2}{*}{ NR } & \multirow[t]{2}{*}{$\begin{array}{l}\text { Gmed } \\
\text { Gmin }\end{array}$} & & \multirow[t]{2}{*}{$\checkmark$} & \multirow{2}{*}{$\begin{array}{l}\text { Inter- } \\
\text { rater } \\
\text { k: } 0.86- \\
0.91\end{array}$} \\
\hline & & & NR & & & & & \\
\hline \multirow[t]{2}{*}{ Emery et al., 2019(80) } & \multirow[t]{2}{*}{3} & \multirow[t]{2}{*}{ - PD FSE } & 4 & \multirow[t]{2}{*}{ NR } & \multirow[t]{2}{*}{ TFL } & \multirow[t]{2}{*}{$\checkmark$} & & $\begin{array}{l}\text { Intra- } \\
\text { rater }\end{array}$ \\
\hline & & & 1.5 & & & & & $\begin{array}{l}\text { ICC: } \\
0.999- \\
1.0\end{array}$ \\
\hline $\begin{array}{l}\text { Engelken et al., } \\
2014(42)\end{array}$ & 1.5 & - T1 SE & $4-6$ & The pelvis & $\begin{array}{l}\text { Gmax } \\
\text { Gmed }\end{array}$ & & $\checkmark$ & $\begin{array}{l}\text { Intra- } \\
\text { rater }\end{array}$ \\
\hline & & & NR & & Gmin & & & $\begin{array}{l}\text { k: } 0.72- \\
0.92\end{array}$ \\
\hline Flack et al., 2012(65) & 1.5 & • T1 PD & 4 & $\begin{array}{l}\text { The highest } \\
\text { point of iliac }\end{array}$ & $\begin{array}{l}\mathrm{TFL} \\
\text { Gmed }\end{array}$ & $\checkmark$ & & $\begin{array}{l}\text { Intra- } \\
\text { rater }\end{array}$ \\
\hline & & $\begin{array}{l}\text { 3D-fast } \\
\text { field echo }\end{array}$ & NR & $\begin{array}{l}\text { crest } \\
\text { superiorly to } \\
\text { the base of } \\
\text { the lesser } \\
\text { trochanter }\end{array}$ & Gmin & & & $\begin{array}{l}\text { ICC: } \\
0.886- \\
0.994\end{array}$ \\
\hline $\begin{array}{l}\text { Franettovich-Smith et } \\
\text { al. 2017(35) }\end{array}$ & 3 & $\cdot \mathrm{T} 2$ & 5 & $\begin{array}{l}\text { Top of the } \\
\text { iliac crest to }\end{array}$ & $\begin{array}{l}\text { Gmax } \\
\text { Gmed }\end{array}$ & $\checkmark$ & & NA \\
\hline & & & 6 & $\begin{array}{l}\text { the inferior } \\
\text { gluteal fold }\end{array}$ & & & & \\
\hline Gerber et al., 2007(122) & 1.5 & - T1 SE & 8 & NR & Gmax & $\checkmark$ & & $\begin{array}{l}\text { Intra- } \\
\text { rater }\end{array}$ \\
\hline & & & 15 & & & & & $\mathrm{ICC}>0.99$ \\
\hline $\begin{array}{l}\text { Grimaldi et al., } \\
2009 \text { (23) (Gmax/TFL) }\end{array}$ & 1.5 & • T2 FISP & 6 & $\begin{array}{l}\text { Iliac crest to } \\
\text { the most }\end{array}$ & $\begin{array}{l}\text { TFL } \\
\text { Gmax }\end{array}$ & $\checkmark$ & & $\begin{array}{l}\text { Intra- } \\
\text { rater }\end{array}$ \\
\hline $\begin{array}{l}\text { Grimaldi et al., } \\
\text { 2009(24) (GMin/GMed) }\end{array}$ & & & Non & $\begin{array}{l}\text { of the Gmax } \\
\text { muscle }\end{array}$ & & & & $\begin{array}{l}\text { ICC: } 0.87- \\
0.99\end{array}$ \\
\hline $\begin{array}{l}\text { Handsfield et al., } \\
2014(104)\end{array}$ & 3 & $\begin{array}{l}\text {-2D multi- } \\
\text { slice }\end{array}$ & 5 & $\begin{array}{l}\text { Iliac crest to } \\
\text { the ankle }\end{array}$ & $\begin{array}{l}\text { TFL } \\
\text { Gmax }\end{array}$ & $\checkmark$ & & NA \\
\hline & & $\begin{array}{l}\text { sequence } \\
\text { utilising } \\
\text { spiral } \\
\text { gradient } \\
\text { echo }\end{array}$ & NR & joint & $\begin{array}{l}\text { Gmed } \\
\text { Gmin }\end{array}$ & & & \\
\hline Homma et al., & NA & - T1 FSE & 3 & NR & Gmax & $\checkmark$ & & NA \\
\hline & & & 0 & & Gmed & & & \\
\hline
\end{tabular}




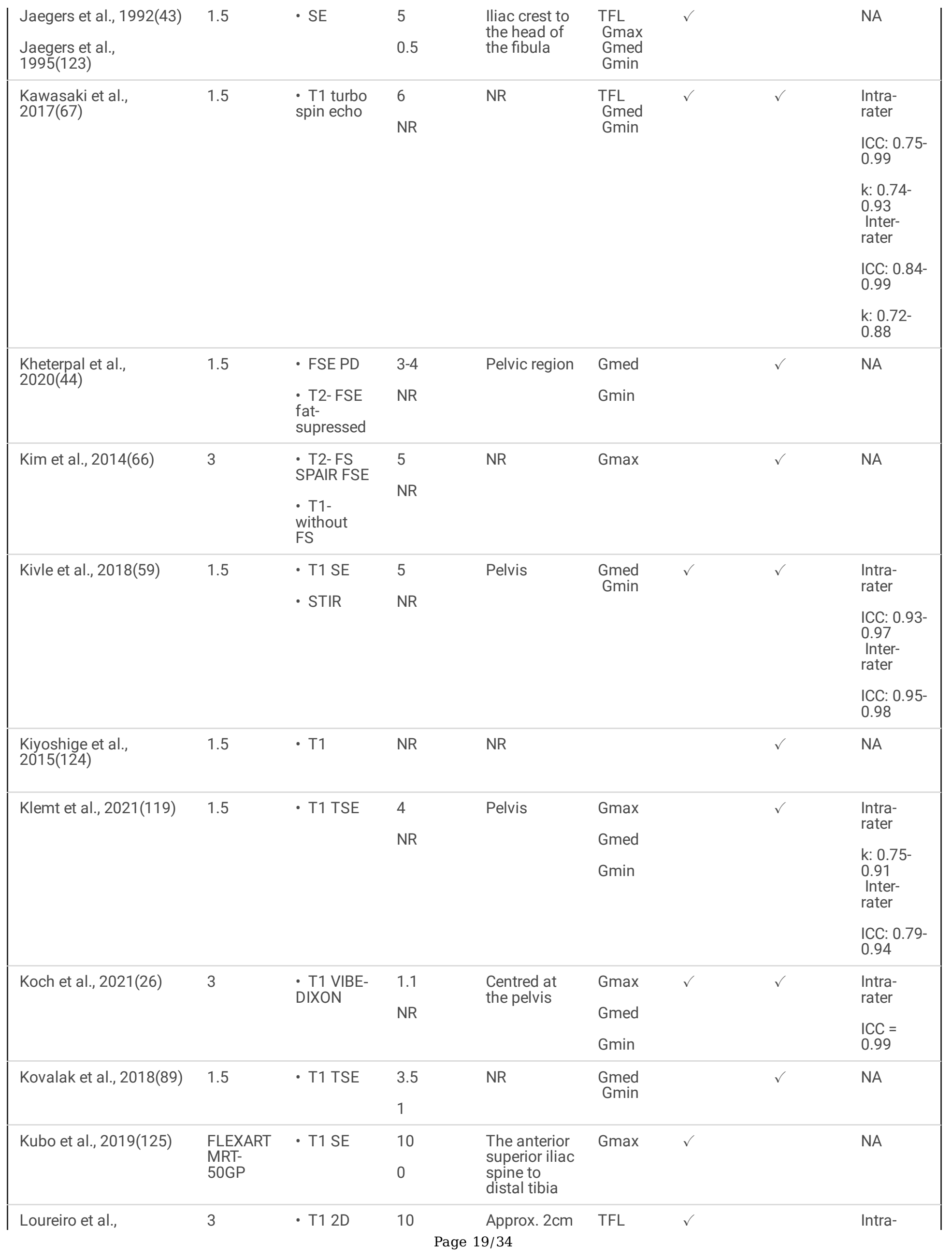




\begin{tabular}{|c|c|c|c|c|c|c|c|}
\hline 2018(68) & & $\begin{array}{l}\text { gradient- } \\
\text { recall } \\
\text { acquisition } \\
\text { in the } \\
\text { steady } \\
\text { state }\end{array}$ & 1 & $\begin{array}{l}\text { superior to } \\
\text { the iliac } \\
\text { crest to } \\
\text { pprox.. } 2 \mathrm{~cm} \\
\text { inferior to } \\
\text { the proximal } \\
\text { tibio-fibula } \\
\text { joint }\end{array}$ & $\begin{array}{l}\text { Gmax } \\
\text { Gmed } \\
\text { Gmin }\end{array}$ & & $\begin{array}{l}\text { rater } \\
\text { ICC } \\
>0.985\end{array}$ \\
\hline $\begin{array}{l}\text { Makridis et al., } \\
2014(126)\end{array}$ & NA & $\cdot \mathrm{T} 1$ & $\begin{array}{l}4-5 \\
\text { NR }\end{array}$ & NR & $\begin{array}{l}\text { Gmed } \\
\text { Gmin }\end{array}$ & $\checkmark$ & NA \\
\hline Malloy et al., 2019(25) & 1.5 & - T1 FSE & $\begin{array}{l}4 \\
5\end{array}$ & $\begin{array}{l}\text { Iliac crest to } \\
\text { the level of } \\
\text { the knee } \\
\text { joint }\end{array}$ & $\begin{array}{l}\text { TFL } \\
\text { Gmax } \\
\text { Gmed } \\
\text { Gmin }\end{array}$ & $\checkmark$ & $\begin{array}{l}\text { Inter- } \\
\text { rater } \\
\text { ICC } \\
0.985- \\
0.992\end{array}$ \\
\hline Marcon et al., 2016(83) & 3 & $\begin{array}{l}\text { - 3-point } \\
\text { mDIXON }\end{array}$ & $\begin{array}{l}\text { NR } \\
0\end{array}$ & $\begin{array}{l}\text { Iliac crest to } \\
\text { ischial } \\
\text { tuberosity }\end{array}$ & $\begin{array}{l}\text { Gmed } \\
\text { Gmin }\end{array}$ & $\checkmark$ & $\begin{array}{l}\text { Intra- } \\
\text { rater } \\
\text { ICC: 0.78- } \\
0.95\end{array}$ \\
\hline $\begin{array}{l}\text { Mastenbrook et al., } \\
2017(127)\end{array}$ & 1.5 & $\begin{array}{l}\text { - 3D FS } \\
\text { gradient- } \\
\text { echo }\end{array}$ & $\begin{array}{l}0.82 \\
0\end{array}$ & $\begin{array}{l}\text { Pelvis (ASIS } \\
\text { to } \\
\text { acetabulum) }\end{array}$ & $\begin{array}{l}\text { TFL } \\
\text { Gluteals } \\
\text { (as a } \\
\text { group) }\end{array}$ & $\checkmark$ & $\begin{array}{l}\text { Intra- } \\
\text { rater } \\
\text { ICC: 0.98- } \\
1.00\end{array}$ \\
\hline $\begin{array}{l}\text { Masuda et al., } \\
2003(71)\end{array}$ & 1.5 & - NR & $\begin{array}{l}5 \\
15\end{array}$ & $\begin{array}{l}\text { ASIS to the } \\
\text { head of the } \\
\text { fibula }\end{array}$ & $\begin{array}{l}\text { Gmax } \\
\text { Gmed } \\
\text { Gmin }\end{array}$ & $\checkmark$ & NA \\
\hline Mendis et al., 2014(69) & 1.5 & - T2 FISP & $\begin{array}{l}8 \\
8.8\end{array}$ & $\begin{array}{l}\text { Iliac crest to } \\
\text { just below } \\
\text { the lesser } \\
\text { trochanter } \\
\text { of the femur }\end{array}$ & TFL & $\checkmark$ & $\begin{array}{l}\text { Intra- } \\
\text { rater } \\
\text { ICC 0.87- } \\
1.00\end{array}$ \\
\hline Mendis et al., 2016(56) & 1.5 & - T2 FISP & $\begin{array}{l}7 \\
10.5\end{array}$ & $\begin{array}{l}\text { Top of the } \\
\text { iliac crest to } \\
\text { the hip joint }\end{array}$ & $\begin{array}{l}\text { Gmed } \\
\text { Gmin }\end{array}$ & $\checkmark$ & $\begin{array}{l}\text { Intra- } \\
\text { rater } \\
\text { ICC: } 0.81- \\
0.99\end{array}$ \\
\hline Mendis et al., 2020(45) & 1.5 & - T2 FISP & $\begin{array}{l}8 \\
8.8\end{array}$ & $\begin{array}{l}\text { Iliac crest to } \\
\text { below the } \\
\text { lesser } \\
\text { trochanter } \\
\text { of the femur. }\end{array}$ & $\begin{array}{l}\text { Gmax } \\
\text { Gmed } \\
\text { Gmin }\end{array}$ & $\checkmark$ & $\begin{array}{l}\text { Intra- } \\
\text { rater } \\
\text { ICC: } 0.90- \\
0.99\end{array}$ \\
\hline Miller et al., 2020(50) & 3 & $\cdot \mathrm{T} 1$ & $\begin{array}{l}5 \\
5\end{array}$ & $\begin{array}{l}\text { abdomen, } \\
\text { thigh, and } \\
\text { shank }\end{array}$ & $\begin{array}{l}\text { TFL } \\
\text { Gmax } \\
\text { Gmed } \\
\text { Gmin }\end{array}$ & $\checkmark$ & NA \\
\hline $\begin{array}{l}\text { Miokovic et al., } \\
2011(70)\end{array}$ & 1.5 & $\cdot \mathrm{NR}$ & $\begin{array}{l}6 \\
0.6\end{array}$ & $\begin{array}{l}\text { From the } \\
\text { iliac crest to } \\
\text { the inferior- } \\
\text { most portion } \\
\text { of the } \\
\text { gluteus } \\
\text { maximus } \\
\text { with a } \\
\text { second } \\
\text { sequence } \\
\text { overlapping } \\
\text { the gluteus } \\
\text { maximus } \\
\text { and } \\
\text { extending to }\end{array}$ & $\begin{array}{l}\text { Gmax } \\
\text { Gmed } \\
\text { Gmin }\end{array}$ & $\checkmark$ & NA \\
\hline
\end{tabular}




\begin{tabular}{|c|c|c|c|c|c|c|c|c|}
\hline \multirow{4}{*}{$\begin{array}{l}\text { Montefiori et al., } \\
2020(55)\end{array}$} & \multirow[t]{4}{*}{1.5} & \multirow[t]{4}{*}{$\cdot \mathrm{T} 1$} & 3 & \multirow[t]{4}{*}{ NR } & TFL & \multirow[t]{4}{*}{$\checkmark$} & & \multirow[t]{4}{*}{ NA } \\
\hline & & & \multirow[t]{3}{*}{ NR } & & Gmax & & & \\
\hline & & & & & Gmed & & & \\
\hline & & & & & Gmin & & & \\
\hline \multirow[t]{2}{*}{ Muller et al., 2010(90) } & \multirow[t]{2}{*}{1.5} & $\cdot$ T1 TSE & 6 & \multirow[t]{2}{*}{ NR } & \multirow[t]{2}{*}{ Gmin } & & \multirow[t]{2}{*}{$\checkmark$} & \multirow[t]{2}{*}{ NA } \\
\hline & & $\cdot$ TIRM & NR & & & & & \\
\hline \multirow[t]{3}{*}{ Muller et al., 2011a(92) } & \multirow[t]{3}{*}{1.5} & • T1 TSE & 6 & \multirow[t]{3}{*}{ NR } & \multirow{3}{*}{$\begin{array}{l}\text { Gmed } \\
\text { Gmin }\end{array}$} & & \multirow[t]{3}{*}{$\checkmark$} & \multirow{3}{*}{$\begin{array}{l}\text { Inter- } \\
\text { rater } \\
\text { k: } 0.51- \\
0.89\end{array}$} \\
\hline & & $\cdot$ TIRM & NR & & & & & \\
\hline & & & & & & & & \\
\hline \multirow[t]{2}{*}{$\begin{array}{l}\text { Muller et al., } \\
2011 \mathrm{~b}(128)\end{array}$} & \multirow[t]{2}{*}{1.5} & \multirow[t]{2}{*}{$\cdot \mathrm{T} 1$} & \multirow[t]{2}{*}{ NR } & \multirow[t]{2}{*}{ NR } & \multirow[t]{2}{*}{ Gmed } & & \multirow[t]{2}{*}{$\checkmark$} & $\begin{array}{l}\text { Inter- } \\
\text { rater }\end{array}$ \\
\hline & & & & & & & & $\begin{array}{l}\text { k: } 0.51- \\
0.89\end{array}$ \\
\hline \multirow{2}{*}{$\begin{array}{l}\text { Niinimäki et al., } \\
2016 \text { (129) } \\
\text { Niinimäki et al., } \\
2019(130)\end{array}$} & \multirow[t]{2}{*}{1.5} & \multirow[t]{2}{*}{ • T1 VIBE } & 1 & \multirow{2}{*}{$\begin{array}{l}\text { From the } \\
\text { most } \\
\text { proximal } \\
\text { aspect of } \\
\text { the femoral } \\
\text { head to the } \\
\text { distal-most } \\
\text { aspect of } \\
\text { the greater } \\
\text { trochanter }\end{array}$} & Gmax & $\checkmark$ & & NA \\
\hline & & & 0 & & & & & \\
\hline Peiris et al., 2020(46) & 3 & $\begin{array}{l}\cdot \mathrm{T} 12 \mathrm{D} \\
\mathrm{FSE}\end{array}$ & 10 & NR & $\begin{array}{l}\text { Gmax } \\
\text { Gmed }\end{array}$ & $\checkmark$ & $\checkmark$ & $\begin{array}{l}\text { Intra- } \\
\text { rater }\end{array}$ \\
\hline & & & NR & & Gmin & & & $\begin{array}{l}\text { ICC: 0.78- } \\
1.00 \\
\text { Inter- } \\
\text { rater }\end{array}$ \\
\hline & & & & & & & & $I C C=0.99$ \\
\hline $\begin{array}{l}\text { Pfirrmann et al., } \\
2005(61)\end{array}$ & 1.5 & - STIR & $3-4$ & NR & Gmed & & $\checkmark$ & NA \\
\hline & & - T1 SE & NR & & & & & \\
\hline Reito et al., 2016(131) & 1.5 & $\cdot \mathrm{T} 1 \mathrm{FSE}$ & 6.5 & NR & Gmax & $\checkmark$ & & NA \\
\hline & & $\cdot \mathrm{STIR}$ & 1.8 & & $\mathrm{Gmin}$ & & & \\
\hline Rodríguez-Roiz et al., & 1.5 & $\cdot \mathrm{T} 1$ & 5 & NR & TFL & $\checkmark$ & & NA \\
\hline & & & NR & & & & & \\
\hline $\begin{array}{l}\text { Rothwell et al., } \\
2019(132)\end{array}$ & 3 & - T1 SE & 5 & NR & $\begin{array}{l}\text { TFL } \\
\text { Gmax }\end{array}$ & $\checkmark$ & & $\begin{array}{l}\text { Intra- } \\
\text { rater }\end{array}$ \\
\hline & & & 0 & & $\begin{array}{l}\text { Gmed } \\
\text { Gmin }\end{array}$ & & & $\begin{array}{l}\text { ICC: } 0.97 \\
\pm 0.03\end{array}$ \\
\hline $\begin{array}{l}\text { Ruckenstuhl et al., } \\
2020(49)\end{array}$ & NR & - MARS & NR & NR & Gmed & & $\checkmark$ & NA \\
\hline Rykov et al., 2021(86) & 1.5 & $\cdot \mathrm{T} 1$ & NR & NR & TFL & & $\checkmark$ & NA \\
\hline & & $\cdot \mathrm{STIR}$ & & & Gmax & & & \\
\hline & & & & & Gmed & & & \\
\hline & & & & & Gmin & & & \\
\hline
\end{tabular}




\begin{tabular}{|c|c|c|c|c|c|c|c|c|}
\hline $\begin{array}{l}\text { Sakamaki et al., } \\
2011(133)\end{array}$ & 1.5 & - T1 SE & $\begin{array}{l}10 \\
0\end{array}$ & $\begin{array}{l}\text { From the } \\
\text { first cervical } \\
\text { vertebra to } \\
\text { the ankle } \\
\text { joint }\end{array}$ & Gmax & $\checkmark$ & & NA \\
\hline $\begin{array}{l}\text { Semciw et al., } \\
2016(134)\end{array}$ & 1.5 & $\cdot \mathrm{T} 1$ & $\begin{array}{l}6 \\
0\end{array}$ & $\begin{array}{l}\text { From above } \\
\text { the iliac } \\
\text { crest to just } \\
\text { below the } \\
\text { distal aspect } \\
\text { of the TFL }\end{array}$ & $\begin{array}{l}\text { Gmed } \\
\text { Gmin }\end{array}$ & $\checkmark$ & & NA \\
\hline $\begin{array}{l}\text { Skorupska et al., } \\
2016(57)\end{array}$ & 1.5 & $\cdot \mathrm{T} 2$ & $\begin{array}{l}4 \\
0\end{array}$ & $\begin{array}{l}\text { From the } \\
\text { lumbar } \\
\text { spine down } \\
\text { to pelvis and } \\
\text { upper thigh }\end{array}$ & $\begin{array}{l}\text { Gmax } \\
\text { Gmed } \\
\text { Gmin }\end{array}$ & $\checkmark$ & & $\begin{array}{l}\text { Inter- } \\
\text { rater } \\
\\
\text { ICC: } \\
0.848- \\
>0.90\end{array}$ \\
\hline $\begin{array}{l}\text { Springer et al., } \\
2012(73)\end{array}$ & 1.5 & • T1 TSE & $\begin{array}{l}6 \\
N R\end{array}$ & NR & $\begin{array}{l}\text { Gmed } \\
\text { Gmin }\end{array}$ & $\checkmark$ & & \\
\hline $\begin{array}{l}\text { Sugisaki et al., } \\
2018(105)\end{array}$ & 1.5 & - T1 echo & $\begin{array}{l}7 \\
15\end{array}$ & $\begin{array}{l}\text { From the } \\
\text { first lumbar } \\
\text { vertebra }(L 1) \\
\text { to the lateral } \\
\text { malleolus of } \\
\text { the fibula }\end{array}$ & $\begin{array}{l}\text { TFL } \\
\text { Gmax } \\
\text { Gmed } \\
\text { Gmin }\end{array}$ & $\checkmark$ & & $\begin{array}{l}\text { Intra- } \\
\text { rater } \\
\text { ICC= } 0.99 \\
\text { Inter- } \\
\text { rater } \\
\text { ICC= } 0.99\end{array}$ \\
\hline Sutter et al., 2013(79) & 1.5 & $\begin{array}{l}\cdot \mathrm{T} 1 \\
\cdot \mathrm{STIR}\end{array}$ & NR & NR & $\begin{array}{l}\text { TFL } \\
\text { Gmed } \\
\text { Gmin }\end{array}$ & $\checkmark$ & $\checkmark$ & NA \\
\hline Takada et al., 2018(74) & 1.5 & $\cdot \mathrm{T} 1$ & NR & NR & $\begin{array}{l}\text { TFL } \\
\text { Gmed }\end{array}$ & $\checkmark$ & $\checkmark$ & $\begin{array}{l}\text { Intra- } \\
\text { rater } \\
\text { ICC: } 0.75- \\
0.98 \\
\text { Inter- } \\
\text { rater } \\
\text { ICC: } 0.75- \\
0.98\end{array}$ \\
\hline Takada et al., 2021(75) & 1.5 & $\cdot \mathrm{T} 1$ & $\begin{array}{l}1.5 \\
N R\end{array}$ & $\begin{array}{l}\text { Lower pelvis } \\
\& \text { hips }\end{array}$ & $\begin{array}{l}\text { TF } \\
\text { Gmed } \\
\text { Gmin }\end{array}$ & $\checkmark$ & $\checkmark$ & $\begin{array}{l}\text { Intra- } \\
\text { rater } \\
\text { ICC: } 0.70- \\
0.98 \\
\text { Inter- } \\
\text { rater } \\
\\
\text { ICC: } 0.70- \\
0.98\end{array}$ \\
\hline $\begin{array}{l}\text { Takahashi et al., } \\
\text { 2019(72) }\end{array}$ & 1.5 & $\cdot \mathrm{T} 1$ & $\begin{array}{l}6 \\
4\end{array}$ & $\begin{array}{l}\text { Trunk and } \\
\text { hip }\end{array}$ & $\begin{array}{l}\text { Gmax } \\
\text { Gmed } \\
\text { Gmin }\end{array}$ & $\checkmark$ & & $\begin{array}{l}\text { Intra- } \\
\text { rater } \\
\text { ICC } \\
>0.987\end{array}$ \\
\hline Tesch et al., 2005(82) & $\begin{array}{l}1 \\
1.5\end{array}$ & $\cdot \mathrm{NR}$ & $\begin{array}{l}10 \\
N R\end{array}$ & NR & Gmax & $\checkmark$ & & NA \\
\hline $\begin{array}{l}\text { Thaunat et al., } \\
2018(95)\end{array}$ & NA & $\begin{array}{l}\cdot \mathrm{T} 1 \text { non- } \\
\text { FS }\end{array}$ & NR & NR & $\begin{array}{l}\text { Gmed } \\
\text { Gmin }\end{array}$ & & $\checkmark$ & NA \\
\hline Tran et al., 2021(120) & 3 & $\begin{array}{l}\text { T12- } \\
\text { point } \\
\text { DIXON }\end{array}$ & $\begin{array}{l}4 \\
N R\end{array}$ & $\begin{array}{l}\text { T11 } \\
\text { vertebral } \\
\text { level to the }\end{array}$ & $\begin{array}{l}\text { Gmax } \\
\text { Gmed }\end{array}$ & $\checkmark$ & $\checkmark$ & $\begin{array}{l}\text { Intra- } \\
\text { rater }\end{array}$ \\
\hline
\end{tabular}




\begin{tabular}{|c|c|c|c|c|c|c|c|c|}
\hline & & & & $\begin{array}{l}\text { inferior-most } \\
\text { portion of } \\
\text { the Gmax }\end{array}$ & Gmin & & & $\begin{array}{l}\text { ICC: } \\
0.938- \\
0.994\end{array}$ \\
\hline Unis et al., 2013(81) & 1.5 & $\cdot \mathrm{STIR}$ & NR & $\begin{array}{l}\text { Lower pelvis } \\
\text { and both } \\
\text { hips }\end{array}$ & TFL & $\checkmark$ & $\checkmark$ & NA \\
\hline \multirow{4}{*}{$\begin{array}{l}\text { Vasarhelyi et al., } \\
2020(48)\end{array}$} & \multirow[t]{4}{*}{ NR } & $\cdot \mathrm{T} 2$ & \multirow[t]{4}{*}{ NR } & \multirow[t]{4}{*}{ NR } & TFL & & \multirow[t]{4}{*}{$\checkmark$} & \multirow[t]{4}{*}{ NA } \\
\hline & & \multirow[t]{3}{*}{$\cdot \mathrm{STIR}$} & & & \multicolumn{2}{|l|}{ Gmax } & & \\
\hline & & & & & \multicolumn{2}{|l|}{ Gmed } & & \\
\hline & & & & & \multicolumn{2}{|l|}{ Gmin } & & \\
\hline \multirow{2}{*}{$\begin{array}{l}\text { von Roth et al., } \\
2014(93)\end{array}$} & \multirow[t]{2}{*}{1.5} & \multirow[t]{2}{*}{ • T1 TSE } & 6 & \multirow[t]{2}{*}{ NR } & \multirow[t]{2}{*}{ Gmed } & & \multirow[t]{2}{*}{$\checkmark$} & \multirow[t]{2}{*}{ NA } \\
\hline & & & NR & & & & & \\
\hline \multirow[t]{2}{*}{ Winkler et al., 2018(94) } & \multirow[t]{2}{*}{ NA } & \multirow[t]{2}{*}{$\cdot \mathrm{T} 1$} & 5 & \multirow[t]{2}{*}{ NR } & \multirow[t]{2}{*}{ Gmed } & \multirow[t]{2}{*}{$\checkmark$} & \multirow[t]{2}{*}{$\checkmark$} & \multirow[t]{2}{*}{ NA } \\
\hline & & & NR & & & & & \\
\hline \multirow[t]{4}{*}{ Yang et al., 2021(77) } & & \multirow{4}{*}{$\begin{array}{l}\dot{\mathrm{PD}} \mathrm{T} 2 \mathrm{FS} \\
\end{array}$} & 3.5 & \multirow[t]{4}{*}{ Hip } & TFL & $\checkmark$ & & \multirow{4}{*}{$\begin{array}{l}\text { Intra- } \\
\text { rater } \\
\text { ICC >0.9 }\end{array}$} \\
\hline & & & \multirow[t]{3}{*}{ NR } & & Gmax & & & \\
\hline & & & & & Gmed & & & \\
\hline & & & & & Gmin & & & \\
\hline \multirow[t]{2}{*}{ Yasuda et al., 2014(78) } & \multirow[t]{2}{*}{1.5} & \multirow[t]{2}{*}{ - T1 SE } & 10 & \multirow{2}{*}{$\begin{array}{l}\text { From the top } \\
\text { edge of the } \\
\text { great } \\
\text { trochanter to } \\
\text { the lateral } \\
\text { condyle of } \\
\text { femur }\end{array}$} & Gmax & $\checkmark$ & & NA \\
\hline & & & 0 & & & & & \\
\hline Yuksel et al., 2009(135) & 1.5 & $\cdot \mathrm{T} 1$ & NR & NR & TFL & $\checkmark$ & & NA \\
\hline & & • T2 FSE & & & & & & \\
\hline $\begin{array}{l}\text { Zacharias et al., } \\
2016(22)\end{array}$ & 3 & $\cdot$ T1 FSE & 6 & $\begin{array}{l}\text { Iliac crest to } \\
\text { distal }\end{array}$ & $\begin{array}{l}\text { TFL } \\
\text { Gmax }\end{array}$ & $\checkmark$ & $\checkmark$ & $\begin{array}{l}\text { Inter- } \\
\text { rater }\end{array}$ \\
\hline $\begin{array}{l}\text { Zacharias et al., } \\
2018(21)\end{array}$ & & & 0 & $\begin{array}{l}\text { insertion of } \\
\text { TFL }\end{array}$ & $\begin{array}{l}\text { Gmed } \\
\text { Gmin }\end{array}$ & & & $\begin{array}{l}\text { ICC: } 0.80- \\
0.98\end{array}$ \\
\hline Zhao et al 2020(47) & 3 & $\cdot \mathrm{T} 2$ & NR & NR & TFL & $\checkmark$ & $\checkmark$ & NA \\
\hline
\end{tabular}

coV-co-efficient of variance FISP- true fast imaging with steady state precession FS- fat supressed FSE-fast spin echo Gmax-gluteus maximus Gmed- gluteus medius GMin- gluteus minimus MARS- Metal Artifact Reduction Sequence MEDIC- multi-echo data image combination NA- not assessed NR- not reported PD- proton density SE- spin echo SPAIR- spectral attenuated inversion recovery STIR- short tau inversion recovery T1-T1 weighted, T2-T2 weighted TFL- tensor fascia latae TSE- turbo spin echo TIRM- turboinversion recovery magnitude VIBE- gradient echo volumetric interpolated breath-hold

Table 2 Volume measurement outcomes for individual studies 


\begin{tabular}{|c|c|c|c|c|}
\hline Citation & $\begin{array}{l}\text { Muscle } \\
\text { segmentation: } \\
\text { Manual/ } \\
\text { automatic }\end{array}$ & $\begin{array}{l}\text { Volume } \\
\text { Full/partial }\end{array}$ & Software used & Equation \\
\hline $\begin{array}{l}\text { Ackland et al. } \\
2019(58)\end{array}$ & $\begin{array}{l}\text { Semi- } \\
\text { automatic }\end{array}$ & $\begin{array}{l}\text { Full } \\
\text { (excl. fat) }\end{array}$ & $\begin{array}{l}\text { Amira FEI } \\
\text { (V 5.3.3, FEI } \\
\text { Visualization } \\
\text { Sciences Group) }\end{array}$ & $\begin{array}{l}\text { Estimated from CSAs, multiplied by slice thickness, } \\
\text { normalised to body weight }\end{array}$ \\
\hline $\begin{array}{l}\text { Amabile et al. } \\
2017(103)\end{array}$ & Manual & Full & $\begin{array}{l}\text { Imaging software } \\
\text { developed by } \\
\text { researchers' } \\
\text { institution }\end{array}$ & "Volume" was normalized to subject height \\
\hline $\begin{array}{l}\text { Belzunce et } \\
\text { al., 2020(52) }\end{array}$ & $\begin{array}{l}\text { Automatic } \\
\& \\
\text { Manual }\end{array}$ & $\begin{array}{l}\text { Partial } \\
\text { (excl. top \& } \\
\text { bottom } \\
\text { extremes, \& } \\
\text { fat) }\end{array}$ & $\begin{array}{l}\text { Simpleware }^{\mathrm{TM}} \\
\text { (V 2018.12, ScanIP) }\end{array}$ & Estimated from CSAs \\
\hline $\begin{array}{l}\text { Belzunce et } \\
\text { al., 2021(85) }\end{array}$ & Automatic & Full & $\begin{array}{l}\text { Simpleware }^{\mathrm{TM}} \\
(\text { V 2020.6, ScanIP) }\end{array}$ & Estimated from CSAs, normalised to body weight \\
\hline $\begin{array}{l}\text { Cowan et al., } \\
\text { 2019(19) }\end{array}$ & Manual & Full & $\begin{array}{l}\text { 3D-DOCTOR } \\
\text { (Able Software } \\
\text { Corp.) }\end{array}$ & Estimated from CSAs, multiplied by slice thickness \\
\hline $\begin{array}{l}\text { Dorado } 2020 \\
\text { et al., } \\
2020(51)\end{array}$ & Manual & Full & $\begin{array}{l}\text { Slice O'matic } \\
\text { (V 4.3, Tomovision } \\
\text { Inc) }\end{array}$ & Estimated from CSAs \\
\hline $\begin{array}{l}\text { Flack et al., } \\
2012(65)\end{array}$ & $\begin{array}{l}\text { Semi- } \\
\text { automatic }\end{array}$ & $\begin{array}{l}\text { Full } \\
\text { (excl. fat) }\end{array}$ & $\begin{array}{l}\text { OsiriX package } \\
\text { (V 2.7.5) }\end{array}$ & Estimated from CSAs, multiplied by slice thickness \\
\hline $\begin{array}{l}\text { Franettovich } \\
\text { Smith et al., } \\
\text { 2017(136) }\end{array}$ & Manual & Full & $\begin{array}{l}\text { OsiriX package } \\
\text { (V 5.7) }\end{array}$ & Estimated from CSAs, multiplied by slice thickness \\
\hline $\begin{array}{l}\text { Grimaldi et } \\
\text { al., } \\
\text { 2009a (23) } \\
\text { Grimaldi et } \\
\text { al., } \\
\text { 2009b (24) }\end{array}$ & Manual & Full & $\begin{array}{l}\text { Osiris package } \\
\text { (V 4.19) }\end{array}$ & Estimated from CSAs, multiplied by slice thickness \\
\hline $\begin{array}{l}\text { Handsfield et } \\
\text { al.,2014(104) }\end{array}$ & Manual & Full & $\begin{array}{l}\text { Software written in } \\
\text { Matlab } \\
\text { (The Math works } \\
\text { Inc.) }\end{array}$ & $\begin{array}{l}\text { Estimated from CSAs with normalised to body mass \& } \\
\text { height }\end{array}$ \\
\hline $\begin{array}{l}\text { Homma et al., } \\
\text { 2019(106) }\end{array}$ & Manual & Full & $\begin{array}{l}\text { ZedHip } \\
\text { (Lexi Co., Ltd.) }\end{array}$ & Estimated from CSAs, multiplied by slice thickness \\
\hline $\begin{array}{l}\text { Jaegers et al., } \\
\text { 1992(43) } \\
\text { Jaegers et al., } \\
\text { 1995(123) }\end{array}$ & Manual & Full & $\begin{array}{l}\text { Obex } \\
\text { (Cerebrum) }\end{array}$ & Estimated from CSAs \\
\hline $\begin{array}{l}\text { Koch et al., } \\
2021(26)\end{array}$ & Manual & Partial & $\begin{array}{l}\text { ITK-Snap Software } \\
\text { (V 3.6) }\end{array}$ & Estimated from CSAs \\
\hline
\end{tabular}

Page 24/34 


\begin{tabular}{|c|c|c|c|c|}
\hline $\begin{array}{l}\text { Kubo et al., } \\
2019(125)\end{array}$ & Manual & Full & $\begin{array}{l}\text { Osirix package } \\
\text { (DICOM image } \\
\text { analysis) }\end{array}$ & Estimated from CSAs, multiplied by slice thickness \\
\hline $\begin{array}{l}\text { Loureiro et } \\
\text { al., 2018(68) }\end{array}$ & $\begin{array}{l}\text { Semi- } \\
\text { automatic }\end{array}$ & Full & Mimics & Estimated from CSAs \\
\hline $\begin{array}{l}\text { Makridis et } \\
\text { al., 2014(126) }\end{array}$ & Manual & Full & NR & Estimated from CSAs, multiplied by slice thickness \\
\hline $\begin{array}{l}\text { Marcon et al., } \\
2016(83)\end{array}$ & $\begin{array}{l}\text { Semi- } \\
\text { automatic }\end{array}$ & $\begin{array}{l}\text { Full (excl. } \\
\text { artifacts) }\end{array}$ & $\begin{array}{l}\text { Myrian } 1 \\
\text { (Intrasense) }\end{array}$ & Estimated from CSAs \\
\hline $\begin{array}{l}\text { Mastenbrook } \\
\text { et al., } \\
2017(127)\end{array}$ & $\begin{array}{l}\text { Semi- } \\
\text { automatic }\end{array}$ & Full & $\begin{array}{l}\text { Analyze } 11.0 \\
\text { (AnalyzeDirect, Inc.) }\end{array}$ & Estimated from CSAs \\
\hline $\begin{array}{l}\text { Miller et al., } \\
2020(50)\end{array}$ & Manual & Full & $\begin{array}{l}\text { DICOM software } \\
\text { (V 2.2.0, Horos) }\end{array}$ & $\begin{array}{l}\text { Estimated from CSAs, multiplied by slice thickness, } \\
\text { normalised to body mass }\end{array}$ \\
\hline $\begin{array}{l}\text { Miokovic et } \\
\text { al., 2011(70) }\end{array}$ & Manual & Full & $\begin{array}{l}\text { ImageJ } \\
(\mathrm{V} 1.38 \mathrm{x})\end{array}$ & Estimated from CSAs \\
\hline $\begin{array}{l}\text { Montefiori et } \\
\text { al., 2020(55) }\end{array}$ & $\begin{array}{l}\text { Semi- } \\
\text { automatic }\end{array}$ & Full & $\begin{array}{l}\text { Mimics } \\
\text { (V 20.0, Materialise) }\end{array}$ & Estimated from CSAs \\
\hline $\begin{array}{l}\text { Reito et al., } \\
\text { 2016(131) }\end{array}$ & Manual & NR & NR & $\begin{array}{l}\text { "Muscle atrophy was assessed as a decrease in volume } \\
\text { and the appearance of fatty change relative to the } \\
\text { contralateral, non-operated side." }\end{array}$ \\
\hline $\begin{array}{l}\text { Rothwell et } \\
\text { al., 2019(132) }\end{array}$ & Manual & Full & $\begin{array}{l}\text { OsiriX Lite } \\
\text { (V 8.0.1, Pixmeo) }\end{array}$ & $\begin{array}{l}\text { Estimated from CSAs, multiplied by slice thickness, } \\
\text { normalised to body mass \& height }\end{array}$ \\
\hline $\begin{array}{l}\text { Sakamaki et } \\
\text { al., 2011(133) }\end{array}$ & Manual & Full & NR & Estimated from CSAs, multiplied slice thickness \\
\hline $\begin{array}{l}\text { Semciw et al., } \\
2016(134)\end{array}$ & Manual & Full & $\begin{array}{l}\text { Sante DICOM Editor } \\
\text { (Santesoft) }\end{array}$ & Estimated from CSAs, multiplied slice thickness \\
\hline $\begin{array}{l}\text { Skorupska et } \\
\text { al., 2016(57) }\end{array}$ & Manual & Full & $\begin{array}{l}\text { ITK-SNAP } \\
(\mathrm{V} 2.2 .0)\end{array}$ & Estimated from CSAs, multiplied by slice thickness \\
\hline $\begin{array}{l}\text { Springer et } \\
\text { al., 2012(73) }\end{array}$ & Manual & Full & $\begin{array}{l}\text { Vitrea } 2 \\
(\mathrm{~V} \text { 4.1.2.0) }\end{array}$ & Estimated from CSAs \\
\hline $\begin{array}{l}\text { Sugisaki et } \\
\text { al., 2018(105) }\end{array}$ & Manual & Full & $\begin{array}{l}\text { OsiriX } \\
(\mathrm{V} 2.4)\end{array}$ & $\begin{array}{l}\text { Estimated from CSAs, multiplied by slice thickness, } \\
\text { normalised to body mass. }\end{array}$ \\
\hline $\begin{array}{l}\text { Tran et al., } \\
2021(120)\end{array}$ & Manual & Full & $\begin{array}{l}\text { The MathWorks, } \\
\text { Inc., Natick, MA, } \\
\text { United States }\end{array}$ & Estimated from CSAs, multiplied by slice thickness \\
\hline $\begin{array}{l}\text { Winkler et al., } \\
\text { 2018(94) }\end{array}$ & Manual & Full & $\begin{array}{l}\text { PACS workstation } \\
\text { OsiriX }\end{array}$ & Estimated from CSAs \\
\hline $\begin{array}{l}\text { Zacharias et } \\
\text { al., 2016(22) } \\
\text { Zacharias et } \\
\text { al., 2018(21) }\end{array}$ & Manual & $\begin{array}{l}\text { Full } \\
\text { (excl. fat) }\end{array}$ & Sante DICOM editor & Estimated from CSAs, multiplied by slice thickness \\
\hline
\end{tabular}

CSA-cross sectional area Excl.- excluding GMax-Gluteus maximus NR- not reported V-Version 
Table 3 Cross sectional area measurement outcomes for individual studies

Page 26/34 


\begin{tabular}{|c|c|c|c|c|}
\hline Citation & Muscles & $\begin{array}{l}\text { Manual/ } \\
\text { automatic }\end{array}$ & Single/multiple slice & Software used \\
\hline \multirow{4}{*}{$\begin{array}{l}\text { Arokoski et al., } \\
2002(76)\end{array}$} & TFL & Manual & Single slice & NR \\
\hline & GMax & & & \\
\hline & GMed & & & \\
\hline & GMin & & & \\
\hline \multirow{2}{*}{$\begin{array}{l}\text { Emery et al., } \\
2019(80)\end{array}$} & TFL & Manual & Multiple & DICOM \\
\hline & & & $\begin{array}{l}\text { CSA measured for four consecutive } \\
\text { slices and mean was used }\end{array}$ & \\
\hline \multirow{2}{*}{$\begin{array}{l}\text { Homma et al., } \\
\text { 2019(106) }\end{array}$} & GMax & Manual & Multiple & ZedHip \\
\hline & GMed & & $\begin{array}{l}\text { CSA measured at two anatomical } \\
\text { levels }\end{array}$ & (Lexi Co., Ltd.) \\
\hline \multirow{3}{*}{$\begin{array}{l}\text { Kawasaki et al., } \\
2017(67)\end{array}$} & TFL & Manual & Single slice & NR \\
\hline & GMed & & & \\
\hline & GMin & & & \\
\hline \multirow{2}{*}{$\begin{array}{l}\text { Kivle et al., } \\
\text { 2018(59) }\end{array}$} & GMed & Manual & Single slice & PACS Sectra \\
\hline & GMin & & & $(\mathrm{V} 16)$ \\
\hline \multirow{4}{*}{$\begin{array}{l}\text { Malloy et al., } \\
2019(25)\end{array}$} & & Manual & Single slice & $\begin{array}{l}\text { Picture archiving and communication } \\
\text { system workstation software }\end{array}$ \\
\hline & GMax & & & \\
\hline & GMed & & & \\
\hline & GMin & & & \\
\hline \multirow{3}{*}{$\begin{array}{l}\text { Masuda et al., } \\
2003(71)\end{array}$} & GMax & Manual & Single slice & Public domain imaging software \\
\hline & GMed & & The maximum CSAs & 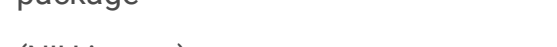 \\
\hline & GMin & & & (IVIF Image) \\
\hline \multirow{2}{*}{$\begin{array}{l}\text { Mendis et al., } \\
2014(69)\end{array}$} & TFL & Manual & Multiple & Image J \\
\hline & & & $\begin{array}{l}\text { Mean CSA was measured from } 3 \\
\text { consecutive slices }\end{array}$ & $(\mathrm{V} 1.43 \mathrm{u})$ \\
\hline \multirow{2}{*}{$\begin{array}{l}\text { Mendis et al., } \\
2016(56)\end{array}$} & GMed & Manual & Multiple & Image J \\
\hline & GMin & & $\begin{array}{l}\text { Mean CSA was measured from } 3 \\
\text { consecutive slices }\end{array}$ & $(\mathrm{V} 1.4)$ \\
\hline \multirow{3}{*}{$\begin{array}{l}\text { Mendis et al., } \\
2020(45)\end{array}$} & GMax & Manual & Multiple & Image J \\
\hline & GMed & & Mean CSA was measured from 3 & $(\mathrm{~V} 1.43 \mathrm{u})$ \\
\hline & GMin & & & \\
\hline $\begin{array}{l}\text { Niinimäki et al., } \\
\text { 2016(129) }\end{array}$ & GMax & Manual & Single slice & Osirix program \\
\hline \multicolumn{5}{|l|}{$\begin{array}{l}\text { Niinimäki et al., } \\
2019(130)\end{array}$} \\
\hline \multirow{3}{*}{$\begin{array}{l}\text { Peiris et al., } \\
\text { 2020(46) }\end{array}$} & GMax & Manual & Single slice & Osirix program \\
\hline & GMed & & & \\
\hline & GMin & & & \\
\hline $\begin{array}{l}\text { Rodriguez-Roiz et } \\
\text { al., 2017(62) }\end{array}$ & TFL & Manual & Single slice & NR \\
\hline
\end{tabular}




\begin{tabular}{|c|c|c|c|c|}
\hline $\begin{array}{l}\text { Springer et al., } \\
2012(73)\end{array}$ & $\begin{array}{l}\text { GMed } \\
\text { GMin }\end{array}$ & Manual & Single slice & $\begin{array}{l}\text { Vitrea } 2 \\
\text { (V 4.1.2.0) }\end{array}$ \\
\hline $\begin{array}{l}\text { Sutter et al., } \\
2013(79)\end{array}$ & $\begin{array}{l}\text { TFL } \\
\text { GMax } \\
\text { GMed } \\
\text { GMin }\end{array}$ & Manual & Single slice & NR \\
\hline $\begin{array}{l}\text { Takada et al., } \\
\text { 2018(74) }\end{array}$ & $\begin{array}{l}\text { TFL } \\
\text { GMed }\end{array}$ & Manual & Single slice & $\begin{array}{l}\text { ImageJ software (National Institute of } \\
\text { Mental Health) }\end{array}$ \\
\hline $\begin{array}{l}\text { Takada et al., } \\
\text { 2021(75) }\end{array}$ & $\begin{array}{l}\text { TFL } \\
\text { GMed } \\
\text { GMin }\end{array}$ & Manual & Single slice & $\begin{array}{l}\text { ImageJ software (National Institute of } \\
\text { Health, USA) }\end{array}$ \\
\hline $\begin{array}{l}\text { Takahashi et al., } \\
\text { 2019(72) }\end{array}$ & $\begin{array}{l}\text { GMax } \\
\text { GMed } \\
\text { GMin }\end{array}$ & Manual & $\begin{array}{l}\text { Single slice } \\
\text { Maximum CSAs }\end{array}$ & $\begin{array}{l}\text { ImageJ software (National Institute of } \\
\text { Health) }\end{array}$ \\
\hline $\begin{array}{l}\text { Tesch et al., } \\
\text { 2005(82) }\end{array}$ & GMax & Manual & Single slice & Computerized planimetry \\
\hline $\begin{array}{l}\text { Unis et al., } \\
\text { 2013(81) }\end{array}$ & TFL & Manual & Single slice & NR \\
\hline $\begin{array}{l}\text { Yang et al., } \\
2021(77)\end{array}$ & $\begin{array}{l}\text { TFL } \\
\text { GMax } \\
\text { GMed } \\
\text { GMin }\end{array}$ & Manual & Single slice & $\begin{array}{l}\text { ImageJ software } \\
\text { (National Institutes of Health) }\end{array}$ \\
\hline $\begin{array}{l}\text { Yasuda et al., } \\
\text { 2014(78) }\end{array}$ & GMax & Manual & Single slice & $\begin{array}{l}\text { SliceOmatic software (Tomovision } \\
\text { Incorporated) }\end{array}$ \\
\hline $\begin{array}{l}\text { Yuksel et al., } \\
\text { 2009(135) }\end{array}$ & $\begin{array}{l}\text { TFL } \\
\text { GMax }\end{array}$ & Manual & Single slice & NR \\
\hline $\begin{array}{l}\text { Zhao et al., } \\
\text { 2020(47) }\end{array}$ & TFL & NR & Single slice & NR \\
\hline
\end{tabular}

CSA: Cross sectional area, TFL: Tensor fascia latae Gmax: Gluteus maximus GMed: Gluteus medius GMin: Gluteus minimus NR: not reported V: Version

Table 4 Fatty infiltration measurement outcomes for individual studies 


\begin{tabular}{|c|c|c|}
\hline Citation & $\begin{array}{l}\text { Fat Infiltration } \\
\text { Qualitative/Quantitative } \\
\text { Classification system }\end{array}$ & $\begin{array}{l}\text { Divided into } \\
\text { compartments } \\
\text { Yes/No }\end{array}$ \\
\hline $\begin{array}{l}\text { Agten et al., } \\
2017(60)\end{array}$ & $\begin{array}{l}\text { Qualitative } \\
\text { G }\end{array}$ & $\mathrm{N}$ \\
\hline \multirow{2}{*}{$\begin{array}{l}\text { Belzunce et al., } \\
2020(53)\end{array}$} & Quantitative & $\mathrm{N}$ \\
\hline & Ratio of muscle and fat value pixels & \\
\hline \multirow{2}{*}{$\begin{array}{l}\text { Belzunce et al., } \\
2021(85)\end{array}$} & Quantitative & $\mathrm{N}$ \\
\hline & Ratio of muscle and fat value pixels & \\
\hline $\begin{array}{l}\text { Berber et al., } \\
\text { 2015(121) }\end{array}$ & $\begin{array}{l}\text { Qualitative } \\
\text { similar to G }\end{array}$ & $\mathrm{N}$ \\
\hline $\begin{array}{l}\text { Bravo et al., } \\
2013(84)\end{array}$ & $\begin{array}{l}\text { Quantitative } \\
\text { Skeletal muscle lipid concentration (g /100 mL) }\end{array}$ & $\mathrm{N}$ \\
\hline \multirow{2}{*}{$\begin{array}{l}\text { Bremer et al., } \\
2011(87)\end{array}$} & \multirow{2}{*}{$\begin{array}{l}\text { Qualitative } \\
\text { Similar to G }\end{array}$} & $\mathrm{Y}$ \\
\hline & & $\begin{array}{l}\text { Gmed \& Gmin: } \\
\text { AMP }\end{array}$ \\
\hline \multirow{2}{*}{$\begin{array}{l}\text { Burian et al., } \\
2020(54)\end{array}$} & Quantitative & $\mathrm{N}$ \\
\hline & Using a water-fat separation algorithm & \\
\hline $\begin{array}{l}\text { Chi et al., } \\
2015(64)\end{array}$ & $\begin{array}{l}\text { Qualitative } \\
\text { G }\end{array}$ & $\mathrm{N}$ \\
\hline \multirow{2}{*}{$\begin{array}{l}\text { Cowan et al., } \\
2019(19)\end{array}$} & \multirow{2}{*}{$\begin{array}{l}\text { Qualitative } \\
\text { G }\end{array}$} & Y \\
\hline & & $\begin{array}{l}\text { Gmed \& Gmin: } \\
\text { AP }\end{array}$ \\
\hline \multirow[t]{2}{*}{$\begin{array}{l}\text { De Anta-Diaz et } \\
\text { al., 2016(88) }\end{array}$} & $\begin{array}{l}\text { Qualitative } \\
\text { Grade 1: no fat or mild atrophy }\end{array}$ & $\mathrm{N}$ \\
\hline & Grade 2: moderate or severe fatty atrophy & \\
\hline \multirow{2}{*}{$\begin{array}{l}\text { Ebert et al., } \\
2019(63)\end{array}$} & \multirow{2}{*}{$\begin{array}{l}\text { Qualitative } \\
\text { G }\end{array}$} & Y \\
\hline & & $\begin{array}{l}\text { Gmed \& } \\
\text { Gmin: AMP }\end{array}$ \\
\hline $\begin{array}{l}\text { Engelken et al., } \\
2014(42)\end{array}$ & $\begin{array}{l}\text { Qualitative } \\
\text { G \& Q }\end{array}$ & $\mathrm{N}$ \\
\hline $\begin{array}{l}\text { Kawasaki et al., } \\
\text { 2017(67) }\end{array}$ & $\begin{array}{l}\text { Qualitative } \\
\text { Q }\end{array}$ & $\mathrm{N}$ \\
\hline \multirow{2}{*}{$\begin{array}{l}\text { Kheterpal et al., } \\
2020(44)\end{array}$} & Qualitative & $\mathrm{N}$ \\
\hline & $G \& Q$ & \\
\hline \multirow{2}{*}{$\begin{array}{l}\text { Kim et al., } \\
2014(66)\end{array}$} & Qualitative & $\mathrm{N}$ \\
\hline & Similar to G & \\
\hline \multirow{2}{*}{$\begin{array}{l}\text { Kivle et al., } \\
\text { 2018(59) }\end{array}$} & \multirow{2}{*}{$\begin{array}{l}\text { Qualitative } \\
\text { G }\end{array}$} & Y \\
\hline & & $\begin{array}{l}\text { Gmed \& } \\
\text { Gmin: AMP }\end{array}$ \\
\hline \multirow{2}{*}{$\begin{array}{l}\text { Klemt et al., } \\
2021(119)\end{array}$} & Qualitative & $\mathrm{N}$ \\
\hline & G \& Q \& Bal and Lowe classification & \\
\hline \multirow{2}{*}{$\begin{array}{l}\text { Koch et al., } \\
2021(26)\end{array}$} & Quantitative & $\mathrm{Y}$ \\
\hline & Pixel intensity values from the fat only images and the water only images & Gmed: AMP \\
\hline
\end{tabular}

Page 29/34 
Kovalak et al., 2018

Makridis et al., 2014(126)

Marcon et al., 2016(83)

Muller et al., 2010(90)

Qualitative

G

Qualitative

G

Qualitative

G

Quantitative

Fat Signal Fraction $\%=100 \times$ fat $/($ water + fat $)$

$\mathrm{N}$

2011a(92)

Qualitative

G

Qualitative

G

Muller et al

$2011 b(128)$

N

$\mathrm{N}$

Y

Y

Y
Qualitative

Grade 0: no fat infiltration

grade 1: 1-10\% fat infiltration

grade $2: 11-50 \%$ fat infiltration

grade 3 : > 50\% fat infiltration

$\begin{array}{ll}\text { Pfirrmann et I., } & \text { Qualitative } \\ 2005(61) & \text { G }\end{array}$
Gmin: AMP

Gmed \& Gmin:

AMP

Gmed \&

Gmin: AMP

N

Y

Gmed \&

Gmin: AMP

Ruckenstuhl et Qualitative N

al., 2020(49) G

Rykov et al., Qualitative N

2021(86)

Sutter et al., Qualitative $\quad$ N

2013(79) G

Takada et al., Qualitative N

2018(74) G

Takada et al., Qualitative N N N N N N N N N

2021(75) G

Thaunat et al., Qualitative Y

2018(95) G

$\mathrm{N}$

N

$\mathrm{N}$

Y

Gmed: AMP

Tran et al., Quantitative N

2021(120) Intramuscular lipid concentration

Unis et al., Qualitative

2013(81) Presence/absence

Vasarhelyi et al., Quantitative

$\mathrm{N}$

Muscle/fat intensity scores

von Roth et al., Quantitative

Y

2014(93)

\% fat content: "...the quotient of the number of fat-value-pixels and the number of fat-value-

Gmed: AMP pixels added to the number of muscle-value pixels."

Winkler et al., Quantitative

Page $30 / 34$ 
AMP- equal anterior, middle and posterior thirds AP- equally divided into anterior and posterior FSF: Fat Single fraction G- Goutellier classification Gmax- Gluteus maximus Gmed- Gluteus medius Gmin- Gluteus minimus GSF- Greater sciatic foramen GT- greater trochanter Ifat: Mean signal fat intensity Iwater: Mean signal water intensity $\mathbf{N}$ - No Q- The quartile classification TFL-Tensor fascia latae Y-Yes

\section{Figures}

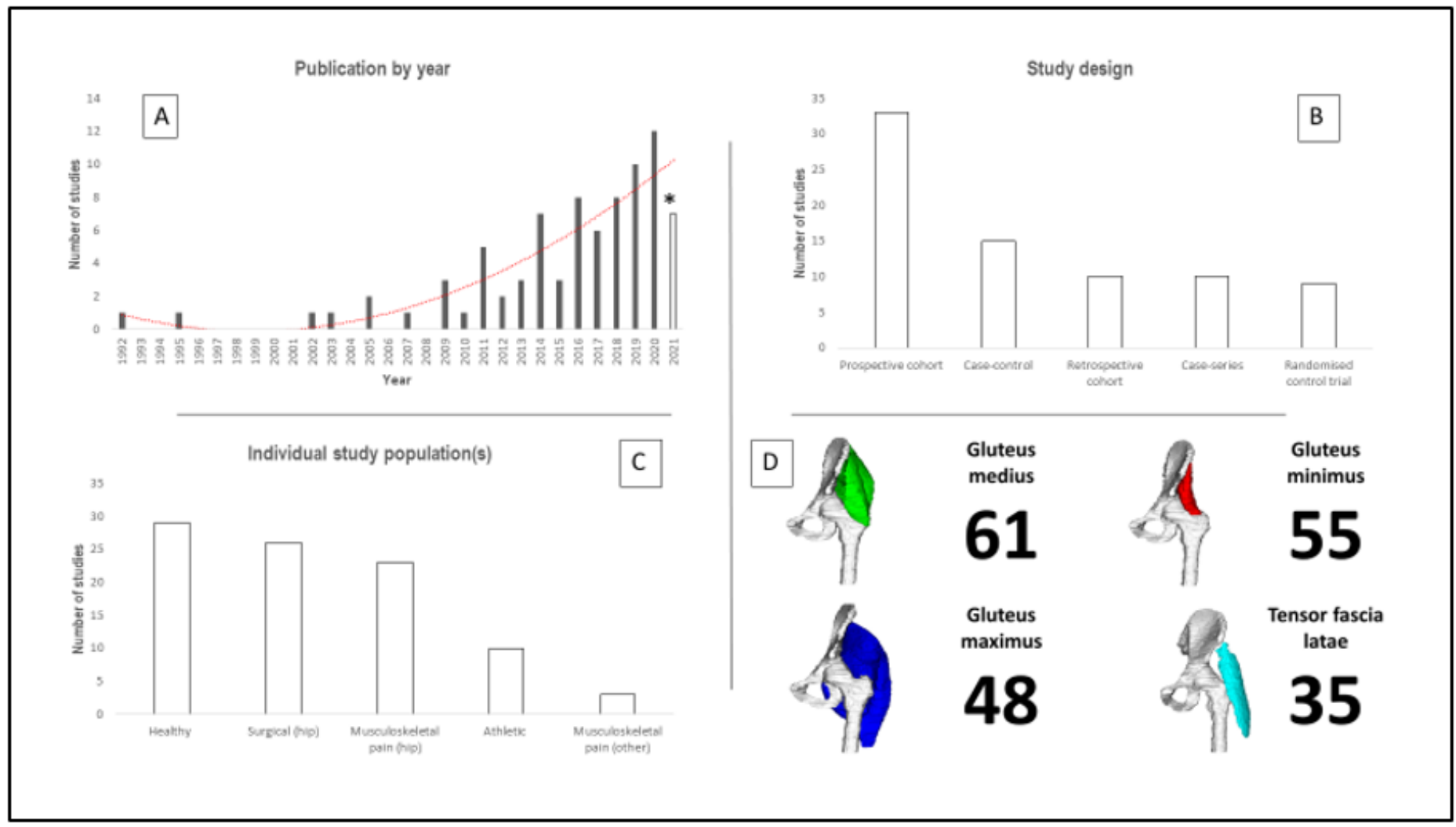

Figure 1

Individual study characteristics: A Publication year of individual studies B Individual study designs C Populations used across individual studies D Lateral hip muscles assessed across individual studies * Incomplete year (January to November '01) 

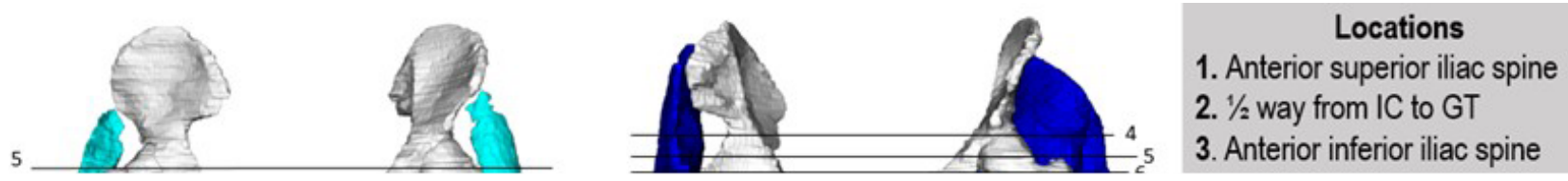

\section{Figure 2}

3-D representation of anatomical levels for each lateral hip muscle.

\section{Figure 3}

Axial DIXON sequence MRI and E-12 anatomical plastinate comparison at anatomical levels for cross sectional area measurement above the hip joint. A At the level of anterior superior iliac spine B Halfway between the iliac crest and the superior tip of the greater trochanter $\mathbf{C}$ Anterior inferior iliac spine; square dotted box surrounds enlarged morphological region of interest (fig. 4); 1gluteus minimus; 2-gluteus medius; 3- gluteus maximus; 4- TFL; 5- ilium; 6- iliacus; 7- psoas major; 8- rectus abdominis 


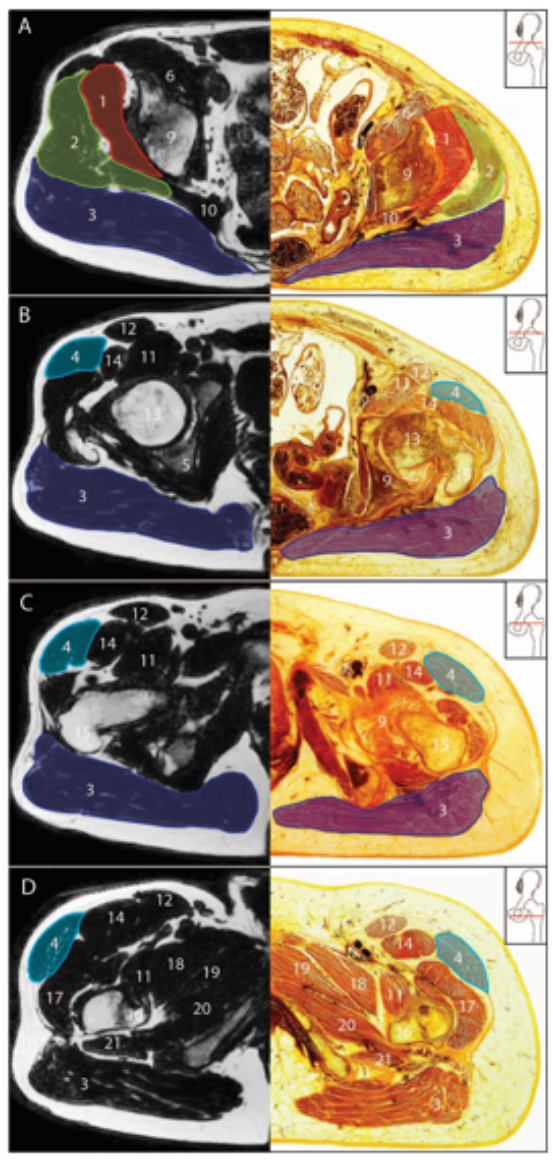

Figure 4

Axial DIXON sequence MRI and E-12 anatomical plastinate comparison at anatomical levels for cross sectional area measurement. A upper border of the acetabulum $\mathbf{B}$ superior tip of the greater trochanter $\mathbf{C}$ lower border of the acetabulum $\mathbf{D}$ lesser trochanter; 1- gluteus minimus; 2- gluteus medius; 3- gluteus maximus; 4- TFL; 5- acetabulum; 6- Iliacus; 9- Acetabulum; 10- Piriformis; 11- Iliopsoas; 12 Sartorius; 13-Rectus femoris; 14- Femoral head; 15- Greater trochanter; 16- lesser trochanter; 17- Vastus lateralis; 18- Pectineus; 19 : Adductor brevis; 20- Adductor magnus; 21- Quadratus femoris

\section{Figure 5}

Enlarged region of interest at the level of anterior inferior iliac spine. A Axial DIXON sequence MRI B E-12 anatomical plastinate C Schematic illustration; round circle indicates feature of interest; Red line- gluteus minimus; Green line- gluteus medius; Dashed red line- partition between gluteus medius and piriformis; Dashed grey line- partition between gluteus maximus with both gluteus medius and piriformis; Red circle- highlights angles between partitions to help identify separation between piriformis and gluteus medius 

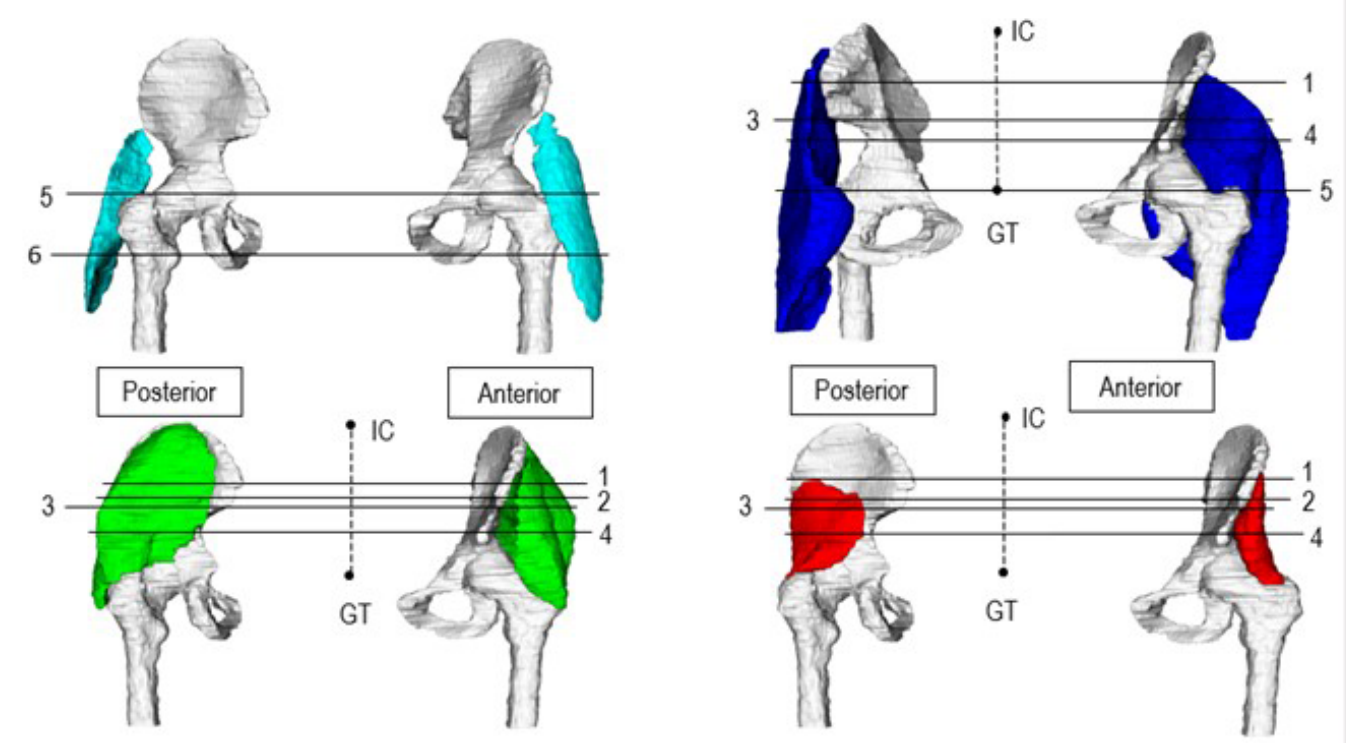

1. $1 / 3^{\text {rd }}$ from IC to GT

2. Anterior superior iliac spine

3. Greater sciatic foramen

4. $2 / 3^{\text {rd }}$ from IC to $G T$

5. GT

6. Lesser trochanter

Tensor fascia latae

Gluteus maximus

Gluteus medius

Gluteus minimus

Abbreviations

GT: Greater trochanter IC: lliac crest

Figure 6

Anatomical levels for fatty infiltration assessment

\section{Supplementary Files}

This is a list of supplementary files associated with this preprint. Click to download.

- Additionalfile1Searchtermsusedforeachmainconcept.docx

- Additionalfile2Databasesearch.docx

- Additionalfile3Additionalfile3PRISMAScRflowdiagram.docx 